\title{
Cationic polymerization of styrene using iron-containing ionic liquid catalysts in an aqueous dispersed medium ${ }^{\dagger}$
}

\author{
Gabriel Victor Simões Dutra ${ }^{1}$ (D), Weslany Silvério Neto ${ }^{1}$ (D), Pedro Henrique Hermes de Araújo ${ }^{3}$ (i), \\ Claudia Sayer $^{3}$ (D), Brenno Amaro da Silveira Neto ${ }^{2 *}$ (D) and Fabricio Machado ${ }^{1 *}$
}

\section{${ }^{1}$ Laboratório de Desenvolvimento de Processos Químicos, Instituto de Química, Universidade de Brasilia - UnB, Brasilia, DF, Brasil}

${ }^{2}$ Laboratório de Química Medicinal e Tecnológica, Instituto de Química, Universidade de Brasilia - UnB, Brasilia, DF, Brasil

${ }^{3}$ Laboratório de Controle de Processos e Polimerização, Departamento de Engenharia Química e Engenharia de Alimentos, Universidade Federal de Santa Catarina - UFSC, Florianópolis, SC, Brasil

tSelected paper presented at the 15th Brazilian Polymer Conference - (15thCBPol) held in Bento Gonçalves, Brazil, on 27-31 October, 2019.

*brenno.ipi@gmail.com,fmachado@unb.br

\begin{abstract}
This work aims to study the cationic miniemulsion polymerization of styrene catalyzed by iron-containing imidazoliumbased ionic liquids. The polystyrenes had very high number-average molar mass around $1300 \mathrm{~kg} \mathrm{~mol}^{-1}$ at $85^{\circ} \mathrm{C}$, molarmass dispersity close to 2.0 and glass transition temperature higher than $102{ }^{\circ} \mathrm{C}$ with average particle diameter that remained practically unchanged during the reaction, indicating that the monomer droplets correspond to the polymerization locus. First-order kinetics up to a limit conversion, along with the increase in molar mass as the temperature decreases, styrene polymerization at low temperatures and catalyst inability to polymerize monomers that react exclusively via free radical and/or anionic polymerization, indicate the cationic nature of polymerization. ${ }^{1} \mathrm{H}-\mathrm{NMR}$ and ${ }^{13} \mathrm{C}-\mathrm{NMR}$ spectra suggested the formation of polystyrene, allowing for tacticity distribution quantification: $10 \%$ isotactic, $20 \%$ atactic and $70 \%$ syndiotactic configurations. TEM micrographs confirmed the formation of spherical polymer nanoparticles and the presence of catalysts in the polymer matrix.
\end{abstract}

Keywords: high molar mass, ionic liquid catalysts, cationic polymerization, miniemulsion polymerization, styrene.

How to cite: Dutra, G. V. S., Silvério Neto, W., Araújo, P. H. H., Sayer, C., Silveira Neto, B. A., \& Machado, F. (2021). Cationic polymerization of styrene using iron-containing ionic liquid catalysts in an aqueous dispersed medium. Polímeros: Ciência Tecnologia, 31(1), e2021005. https://doi.org/10.1590/0104-1428.04620

\section{Introduction}

Polymerizations performed in heterogeneous medium have many advantages, such as high heat removal capacity, low viscosity of the end product, ease of homogenization and manipulation, among others. For these reasons, polymerizations performed in water as a continuous phase are among the most widely used methods for large scale polymer synthesis ${ }^{[1]}$. However, conventional ionic polymerizations are often performed under anhydrous conditions and traces of water should be avoided as catalysts react with water and become inactive ${ }^{[2]}$. In recent decades several efforts have been made in order to develop new catalysts very attractive to the ionic polymerization of different monomers in aqueous dispersed medium ${ }^{[3-12]}$. However, these works use an excessive catalyst $\operatorname{load}(3 \mathrm{to} 10 \mathrm{~mol} \%$ ) and, except for the work of Vasilenko et al. ${ }^{[12]}$, there was the formation of polymers with low molar masses (less than $40 \mathrm{~kg} \mathrm{~mol}^{-1}$ ), similar to that obtained via free radical bulk polymerization. In the literature, there are few reports on cationic polymerization using the miniemulsion technique. Generally, polymerizations occur slowly and at the monomeric/water droplets interface resulting in low molar mass polymers and narrow molar mass distribution ${ }^{[8,9]}$.

In relation to cationic polymerization, recent researches in this area are focused on the development of new catalysts with reusability possibilities, the investigation of new methods using mild experimental conditions, avoiding the use of excess organic solvents, and which allow the more effective control of the final properties of the polymeric materials, such as: molecular structure and molar mass distribution, aiming its use in specific applications.

In this direction, it is worth highlighting the controlled cationic polymerizations of styrene in the presence of water $^{[3,13]}$ and the polymerizations of other cationically polymerized monomers in the presence of ionic liquids, such as $p$-methyl styrene ${ }^{[14]}$, vinyl ether and its derivatives ${ }^{[15,16]}$, and isobutylene ${ }^{[17-19]}$. We recently described the efficient encapsulation of hexadecane in high molar mass polystyrene nanoparticles obtained through cationic miniemulsion polymerization $^{[20]}$, and the synthesis of several ILs catalysts 
intended to produce tailored polystyrene through bulk polymerization process ${ }^{[21]}$.

Alves et al. ${ }^{[22]}$ performed cationic miniemulsion polymerization of styrene using 1-butyl-3-methylimidazolium heptachlorodiferrate ionic liquid $\left(\mathrm{BMI} \cdot \mathrm{Fe}_{2} \mathrm{Cl}_{7}\right)$ as cationic catalyst. Using a low molar ratio of 1:1000 of catalyst/ monomer, the reactions showed colloidal stability and high conversion, $88 \%$, using the temperature of $90{ }^{\circ} \mathrm{C}$ and $6 \mathrm{~h}$ of reaction. The particle size remained practically unchanged until the end of the polymerization process. The viscosimetric-average molar mass obtained at this temperature range, equal to $2231 \mathrm{~kg} \mathrm{~mol}^{-1}$, was higher than those usually found for cationic polymerization. Ayat et al. ${ }^{[23]}$ used a modified natural clay initiator for the cationic copolymerization of vinylidene chloride (VDC) and $\alpha$-methylstyrene ( $\alpha-M S)$. The initiator was obtained by treating montmorillonite clay with sulfuric acid and proved to be an efficient, non-toxic, inexpensive, stable, and noncorrosive catalyst for cationic polymerization. Sang et al. ${ }^{[24]}$ synthesized homopolymers derived from vinyl ether and $p$-substituted styrene by electro-controlled living cationic polymerization. The new method used an organocatalyst, 2,3-dichloro-5,6-dicyano-1,4-benzoquinone (DDQ), which through an electroredox process promoted the oxidation of the chain transfer agent, S-1-isobutoxylethyl S'-ethyl trithiocarbonate to form carbocations. The resulting polymers exhibited narrow and well-defined molar mass distribution and predictability of the functional groups present at the ends of the polymer chain. As a differential, the proposed method allows stopping the polymerization by removing the applied external potential.

In view of this, we extend here the use of different types of iron-containing imidazolium-based ionic liquids: 1-butyl3-methylimidazolium heptachlorodiferrate (BMI $\cdot \mathrm{Fe}_{2} \mathrm{Cl}_{7}$ ), 1-methyl-3-carboxymethylimidazolium heptachlorodiferrate (MAI $\cdot \mathrm{Fe}_{2} \mathrm{Cl}_{7}$ ) and 1,2-Bis(methylimidazolium)ethane bis(heptachlorodiferrate) (bMIE.2 $\left.\mathrm{Fe}_{2} \mathrm{Cl}_{7}\right)$, which efficiently acted as catalysts for styrene bulk polymerization ${ }^{[25,26]}$, expanding its applications as catalysts in a water-phase dispersed polymerization process. The application of these catalysts in this type of polymerization has the following advantages: $\boldsymbol{i}$ ) the incorporation of iron into the anionic group of the ILs, which makes them relatively cheaper and more attractive from an economic point of view when compared to the Lewis acids commonly used in cationic polymerization; ii) the use of ILs, the low catalyst/monomer molar ratio (quite low loading) and the absence of traditional organic solvents favor more sustainable processes; iii) synthesis of polystyrene with very high molar mass; $\boldsymbol{i} \boldsymbol{v}$ ) and possibility of undergoing cationic polymerization ${ }^{[22]}$.

\section{Materials and Methods}

\subsection{Materials}

Monomer (styrene, Merck, 99\%) was purified before use by washing with a $10 \%(w / v)$ aqueous $\mathrm{NaOH}$ solution (Vetec, 99\%). It was then allowed to stand with anhydrous sodium sulfate $\left(\mathrm{Na}_{2} \mathrm{SO}_{4}\right)$ (Dynamic, $99 \%$ ) for $24 \mathrm{~h}$, filtered, vacuum distilled and stored in the refrigerator ${ }^{[27]}$. The reagents 1-methylimidazole (Sigma-Aldrich, 99\%), ethyl acetate (Dynamic, 99.5\%) and dichloromethane (Dynamic, $99.5 \%$ ) were previously vacuum distilled. The other reagents used in the development of the experimental part were of analytical grade and without previous purification, 1-chlorobutane (99\%), chloroacetic acid (99\%), iron (III) chloride anhydrous (97\%), hexadecyltrimethylammonium bromide (CTAB) (cationic surfactant, $99 \%$ ) and hexadecane (co-stabilizer, 99\%) were purchased from Sigma-Aldrich.

\subsection{Synthesis}

\subsubsection{Synthesis of ionic liquids}

The 1-butyl-3-methylimidazolium chloride (BMI.Cl) was synthesized as described by Dupont et al. ${ }^{[28]}$. In a twoneck round-bottom flask under an inert atmosphere of $\mathrm{N}_{2}$ was added 1.3 equiv $(2.40 \mathrm{~mol})$ of 1 -chlorobutane, keeping the system under reflux, magnetic stirring and heating. Slowly, 1.0 equiv $(1.85 \mathrm{~mol})$ of 1 -methylimidazole was added. The solution was heated at reflux at $80^{\circ} \mathrm{C}$ for $48 \mathrm{~h}$. The product was washed with ethyl acetate and a portion of acetonitrile and then dried under reduced pressure at $60{ }^{\circ} \mathrm{C}$ and crystallized to form a white solid. Figure S1 (Supporting Information) shows the ${ }^{1} \mathrm{H}-\mathrm{NMR}$ spectrum.

Yield: $82.1 \%$. ${ }^{1} \mathrm{H}-\mathrm{NMR}\left(\mathrm{CDCl}_{3}, \delta\right.$ in ppm): $0.95(3 \mathrm{H}$, t, $\left.\mathrm{N}\left(\mathrm{CH}_{2}\right)_{3} \mathrm{CH}_{3}\right), 1.38\left(2 \mathrm{H}, \mathrm{m}, \mathrm{N}\left(\mathrm{CH}_{2}\right)_{2} \mathrm{CH}_{2} \mathrm{CH}_{3}\right), 1.90(2 \mathrm{H}$, $\left.\mathrm{m}, \mathrm{NCH}_{2} \mathrm{CH}_{2} \mathrm{CH}_{2} \mathrm{CH}_{3}\right), 4.12\left(3 \mathrm{H}, \mathrm{s}, \mathrm{NCH}_{3}\right), 4.34(2 \mathrm{H}, \mathrm{t}$, $\left.\mathrm{NCH}_{2}\left(\mathrm{CH}_{2}\right)_{2} \mathrm{CH}_{3}\right), 7.58\left(1 \mathrm{H}, \mathrm{t}, \mathrm{CH}_{3} \mathrm{NCHCHN}\right), 7.73(1 \mathrm{H}$, $\left.\mathrm{m}, \mathrm{CH}_{3} \mathrm{NCHCHN}\right)$ and $10.32(1 \mathrm{H}, \mathrm{s}, \mathrm{NCHN})$.

1-methyl-3-carboxymethylimidazolium chloride (MAI-Cl) was synthesized as it follows ${ }^{[29]}$ : In a round bottom flask was added 1.0 equiv $(0.20 \mathrm{~mol})$ of 1 -methylimidazole, 50 $\mathrm{mL}$ of acetonitrile and 1.3 equiv $(0.26 \mathrm{~mol})$ of chloroacetic acid. The solution was heated at reflux at $80{ }^{\circ} \mathrm{C}$ under magnetic stirring and in an inert atmosphere for $48 \mathrm{~h}$. The solid was washed with ethyl acetate until the filtrate was colorless, and then washed with aliquots of acetonitrile. The obtained white solid was vacuum dried at $80^{\circ} \mathrm{C} .{ }^{1} \mathrm{H}-\mathrm{NMR}$ and ${ }^{13} \mathrm{C}$-NMR spectra are shown in Figures $\mathrm{S} 2$ and $\mathrm{S} 3$, Supporting Information.

Yield: 50.4\%. ${ }^{1} \mathrm{H}-\mathrm{NMR}\left(\mathrm{D}_{2} \mathrm{O}, \delta\right.$ in ppm): $3.93(3 \mathrm{H}, \mathrm{s}$, $\left.\mathrm{NCH}_{3}\right), 5.08\left(2 \mathrm{H}, \mathrm{s}, \mathrm{NCH}_{2} \mathrm{COOH}\right), 7.48\left(2 \mathrm{H}, \mathrm{m}, \mathrm{CH}_{3} \mathrm{NCHCHN}\right)$ and $8.78(1 \mathrm{H}, \mathrm{s}, \mathrm{NCHN}) .{ }^{13} \mathrm{C}-\mathrm{NMR}\left(\mathrm{D}_{2} \mathrm{O}, \delta\right.$ in ppm): 38.84 $\left(\mathrm{NCH}_{3}\right), 53.10\left(\mathrm{NCH}_{2} \mathrm{COOH}\right), 126.43\left(\mathrm{CH}_{3} \mathrm{NCHCHN}\right)$, $140.25(\mathrm{NCHN})$ and $173.26\left(\mathrm{NCH}_{2} \mathrm{COOH}\right)$.

1,2-Bis(methylimidazolium)ethane dichloride (bMIE-2Cl) was obtained as described by Ahrens et al. ${ }^{[30]}$. In a round bottom flask was added 1.5 equiv $(0.3 \mathrm{~mol})$ of 1 -methylimidazole, 1.0 equiv $(0.2 \mathrm{~mol})$ of 1,2-dichloroethane and $100 \mathrm{~mL}$ of acetonitrile. The solution was heated at reflux at $80{ }^{\circ} \mathrm{C}$ for $48 \mathrm{~h}$ under magnetic stirring and in an inert atmosphere. The solid was washed with ethyl acetate and small portions of acetonitrile and vacuum dried at $80^{\circ} \mathrm{C}$, resulting in a pale yellow solid. NMR spectra are shown in Figures S4 and $\mathrm{S} 5$ in the Supporting Information.

Yield: 67.8\%. ${ }^{1} \mathrm{H}-\mathrm{NMR}\left(\mathrm{D}_{2} \mathrm{O}, \delta\right.$ in ppm): $3.91(6 \mathrm{H}, \mathrm{s}$, $\left.\mathrm{NCH}_{3}\right), 4.77\left(4 \mathrm{H}, \mathrm{s}, \mathrm{NCH}_{2}\right), 7.45\left(2 \mathrm{H}, \mathrm{d}, \mathrm{CH}_{3} \mathrm{NCHCHN}\right)$ and $7.53\left(2 \mathrm{H}, \mathrm{d}, \mathrm{CH}_{3} \mathrm{NCHCHN}\right) .{ }^{13} \mathrm{C}-\mathrm{NMR}\left(\mathrm{D}_{2} \mathrm{O}, \delta\right.$ in ppm): $38.83\left(\mathrm{NCH}_{3}\right), 51.59\left(\mathrm{NCH}_{2}\right), 124.97\left(\mathrm{CH}_{3} \mathrm{NCHCHN}\right)$, $127.41\left(\mathrm{CH}_{3} \mathrm{NCHCHN}\right)$ and $139.46(\mathrm{NCHN})$.

\subsubsection{Synthesis of iron-containing ionic liquid catalysts}

Previously synthesized ILs were mixed with anhydrous $\mathrm{FeCl}_{3}$ to form the iron-containing ILs catalysts: 1-butyl3-methylimidazolium heptachlorodiferrate ( $\mathrm{BMI} \cdot \mathrm{Fe}_{2} \mathrm{Cl}_{7}$ ), 
1-methyl-3-carboxymethylimidazolium heptachlorodiferrate $\left(\mathrm{MAI} \cdot \mathrm{Fe}_{2} \mathrm{Cl}_{7}\right.$ ) and 1,2-Bis(methylimidazolium)ethane bis(heptachlorodiferrate) (bMIE· $2 \mathrm{Fe}_{2} \mathrm{Cl}_{7}$ ), keeping the following ratio: 2.0 equiv. $\mathrm{FeCl}_{3} / 1.0$ equiv. IL-chloride. Initially, each IL was added to a schlenk and then a defined amount of $\mathrm{FeCl}_{3}$ was added. The reactions were kept under heating, magnetic stirring and inert atmosphere, as shown in Scheme 1. The catalysts were not purified, obtaining a quantitative yield, where $\mathrm{BMI} \cdot \mathrm{Fe}_{2} \mathrm{Cl}_{7}$ is a dark liquid and the others are dark solids at room temperature.

\subsubsection{Miniemulsion polymerization}

The polymerizations were carried in a $150 \mathrm{~mL}$ jacketed glass reactor, integrated with a thermostatic bath at the desired temperature $\left(85,70\right.$ or $\left.55{ }^{\circ} \mathrm{C}\right)$, remaining for $8 \mathrm{~h}$ under constant mechanical stirring of $400 \mathrm{rpm}$ and $\mathrm{N}_{2}$ bubbling. Polymerizations were performed in triplicates, maintaining a catalyst/styrene molar ratio of 1:1000. The formulations used were adapted from Alves et al. ${ }^{[22]}$. Initially, the aqueous phase, made up of $0.36 \mathrm{~g}$ of the cationic surfactant CTAB, and $66 \mathrm{~g}$ of deionized water, and the organic phase, $0.90 \mathrm{~g}$ of hexadecane and $18 \mathrm{~g}$ of styrene, were prepared separately under magnetic stirring at $300 \mathrm{rpm}$ for $20 \mathrm{~min}$ and at room temperature. Then the organic phase was added to the aqueous phase, while maintaining magnetic stirring at $800 \mathrm{rpm}$. After $20 \mathrm{~min}$, the coarse emulsion was miniemulsified using an ultrasonic homogenizer for $1 \mathrm{~min}$ in a $70 \%$ amplitude ice bath (10 s on/ $5 \mathrm{~s}$ off).

Subsequently, a solution consisting of catalyst and $6 \mathrm{~g}$ of water was prepared, leaving it to stir until complete solubilization of the catalyst. First, the miniemulsion and, later the catalytic solution were transferred, in a single step, to the reactor, kept under stirring for $5 \mathrm{~min}$ and $\mathrm{N}_{2}$ bubbling. After the mixing time, the thermostatic bath was integrated with the reactor and a condenser was adapted at one end and the system was kept under $\mathrm{N}_{2}$ bubbling. Aliquots of latex were collected during the reaction. The latex obtained has a light yellow color and the dry polymers are yellow color (Figure S6a, Supporting Information). The dry polymers were purified by solubilization in dichloromethane and then submitted to extraction with distilled water. The organic phase was allowed to stand with anhydrous $\mathrm{Na}_{2} \mathrm{SO}_{4}$ and then filtered and the purified polymer was obtained after evaporation of the solvent (Figure S6b, Supporting Information). 'H-NMR $\left(600 \mathrm{MHz}, \mathrm{CDCl}_{3}\right.$ ) (Figure S7, Supporting Information) $\delta$ (ppm): $0.88\left(6 \mathrm{H}, \mathrm{CH}_{3}\left(\mathrm{CH}_{2}\right)_{14} \mathrm{CH}_{3}\right.$ of hexadecane), 1.26 $\left(28 \mathrm{H}, \mathrm{CH}_{3}\left(\mathrm{CH}_{2}\right)_{14} \mathrm{CH}_{3}\right.$ of hexadecane $), 1.30-1.55(2 \mathrm{H}$, $\left.-\mathrm{CH}_{2} \mathrm{CH}(\mathrm{Ph})-\right), 1.83$ (1H, $\left.-\mathrm{CH}_{2} \mathrm{CH}(\mathrm{Ph})-\right), 6.30-7.08(\mathrm{~m}$, $5 \mathrm{H}, \mathrm{Ar}$ ) - Polystyrene obtained using $\mathrm{BMI} \cdot \mathrm{Fe}_{2} \mathrm{Cl}_{7} /$ styrene molar ratio of $1: 1000$ at $85^{\circ} \mathrm{C}$ and $8 \mathrm{~h}$ of synthesis; $\bar{M}_{n}=1266 \mathrm{~kg} \mathrm{~mol}^{-1}$ and $\bigoplus_{\mathrm{M}}=1.88$.

\subsection{Material Characterization}

The mass-average molar mass $\left(\bar{M}_{w}\right)$ and the numberaverage molar mass $\left(\bar{M}_{n}\right)$ and the dispersity $\left(\bigoplus_{\mathrm{M}}\right)$ of the polymers were determined using a gel permeation chromatograph (Malvern, model Viscotek RImax) equipped with a refractive index detector with a set of three columns of $300 \times 8 \mathrm{~mm}$ mounted in series (KF-802.5, KF-804L and KF-805L) operating at $40{ }^{\circ} \mathrm{C}$. The system was calibrated using polystyrene standards with molar mass ranging from $1.20 \mathrm{~kg} \mathrm{~mol}^{-1}$ to $4500 \mathrm{~kg} \mathrm{~mol}^{-1}$ and monodisperse $\left(\mathrm{Ð}_{\mathrm{M}}\right.$ close to 1.0). Tetrahydrofuran solvent (THF), HPLC grade, was used as the mobile phase with a flow rate of $1 \mathrm{~mL} \cdot \mathrm{min}^{-1}$. Prior to injection, previously prepared solutions (1.5 mg sample/1.0 mL THF) were filtered through hydrophobic polytetrafluoroethylene (PTFE) membranes with $0.45 \mu \mathrm{m}$ pore size and the injection volume was $100 \mu \mathrm{L}$.

The differential scanning calorimetry (DSC) curves were obtained using a Shimadzu model DSC-60 equipment. The initial masses used were approximately $5.0 \mathrm{mg}$ and aluminum crucibles were used. The measurements were made under a helium atmosphere at a flow rate of $30 \mathrm{~mL} \mathrm{~min}^{-1}$, with heating rate of $10{ }^{\circ} \mathrm{C} \mathrm{min}^{-1}$ and two heating ramps (-40 to $180^{\circ} \mathrm{C}$ ). The second heating cycle was used to determine the $T_{G}$ of the polymers.

Nuclear magnetic resonance ( ${ }^{1} \mathrm{H}-\mathrm{NMR}$ and $\left.{ }^{13} \mathrm{C}-\mathrm{NMR}\right)$ spectra were obtained using a Bruker 600 Ascend spectrometer,

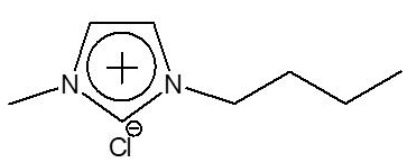

BMI.Cl<smiles></smiles>

MAI.Cl

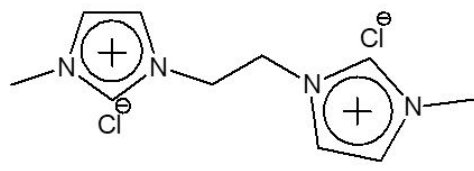

bMIE.2CI

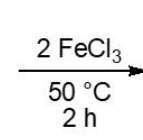

$\mathrm{h}$

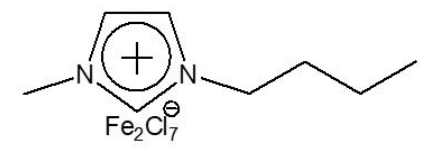

BMI. $\mathrm{Fe}_{2} \mathrm{Cl}_{7}$
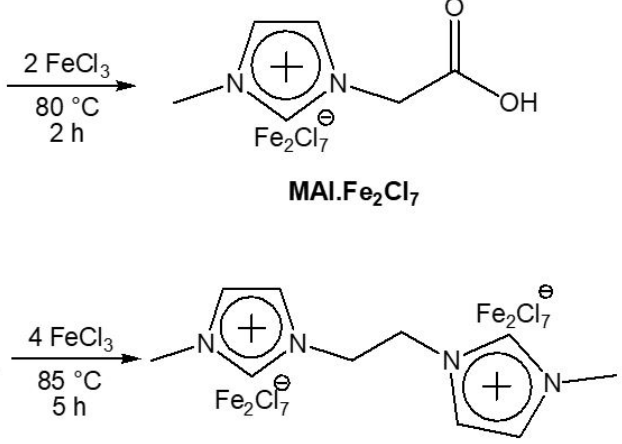

bMIE. $2 \mathrm{Fe}_{2} \mathrm{Cl}_{7}$

Scheme 1. Schematic representation of synthesis route of iron-containing ILs catalysts. 
equipped with a $5 \mathrm{~mm}$ probe operating at $600 \mathrm{MHz}$. About $20 \mathrm{mg}$ of the samples were dissolved in $0.5 \mathrm{~mL}$ of deuterated solvent and the spectra were acquired expressing chemical shifts in parts per million (ppm) and tetramethylsilane (TMS) was used as internal standard.

The average sizes of the monomer droplets (initial Dp) and latex polymer particles (final Dp) and their respective polydispersity indexes (PdI) were determined using the dynamic light scattering technique (DLS) using a Malvern equipament, Zetasizer Nano ZS model. Measurements were made by direct dispersion of a drop in approximately $2.5 \mathrm{~mL}$ of water.

Transmission electron micrographs (TEM) were obtained using a JEOL JEM-2100 microscope operating at $200 \mathrm{kV}$. The samples were initially dispersed in distilled water and sonicated for $15 \mathrm{~min}$. Then a drop of the suspension was applied to a 200 mesh copper containing a supported carbon film and dried at room temperature.

The conversions were obtained by gravimetric data. At predetermined time intervals, aliquots of the reaction medium, about $1.0 \mathrm{~g}$, were removed and added to preweighed aluminum foil capsules treated with 5 drops of $\mathrm{NaOH}$ solution $\left(4 \mathrm{~g} \mathrm{~L}^{-1}\right)^{[8]}$. The capsules were dried in an oven at $60{ }^{\circ} \mathrm{C}$ for approximately $48 \mathrm{~h}$. The conversion was obtained by the ratio of the dry polymer mass to the monomer mass used. The polymer mass was obtained by subtracting the added $\mathrm{NaOH}$ fraction and the non-polymer species (initiator, surfactant and stabilizer).

\section{Results and Discussion}

The polymerizations were performed in accordance with the experimental procedure previously described and aliquots were collected throughout the polymerization process in order to evaluate performance of iron-containing ILs catalysts incorporated in their anionic structure, $\mathrm{BMI} \cdot \mathrm{Fe}_{2} \mathrm{Cl}_{7}$, $\mathrm{MAI} \cdot \mathrm{Fe}_{2} \mathrm{Cl}_{7}$ and bMIE$\cdot 2 \mathrm{Fe}_{2} \mathrm{Cl}_{7}$, and the effect of the reaction temperature on final polymer properties, nanoparticle size and conversion. Table 1 shows the conversion and diameter values of monomer droplets (initial $\mathrm{Dp}$ ) and polymeric particles (final Dp), including polydispersity index (PdI), corresponding to the mean and standard deviation of the essays performed in triplicate, and the values obtained for each synthesis are presented in Table S1 in the Supporting Information. The polymerizations were carried out in triplicate in order to evaluate the reproducibility of the polymerization process and minimize experimental scattering due to gravimetry measurements. Figure 1 shows the evolution of conversion, mean particle diameter and the semilogarithmic plot of monomer concentration for the different synthesis conditions.

The high conversion values indicate that all ILs catalysts were efficiently capable of producing polystyrene. The highest conversions, generally under the same experimental conditions, were achieved using the bMIE $2 \mathrm{Fe}_{2} \mathrm{Cl}_{7}$ catalyst (comparing Entries 2, 5 and 8 and Entries 4, 7 and 10 of Table 1). This behavior was not observed at $70{ }^{\circ} \mathrm{C}$, as Entries 3 and 6 of Table 1 showed the largest standard deviations. This difference in reactivity of the catalysts is due to the higher proportion of the anionic species $\mathrm{Fe}_{2} \mathrm{Cl}_{7}$ in the bMIE. $2 \mathrm{Fe}_{2} \mathrm{Cl}_{7}$ than in the others, since according to Rodrigues et al. ${ }^{[31]}$ these species are responsible for initiating styrene polymerization. In addition, these polymerizations showed a limit conversion of 80 to $90 \%$, related to monomer loss due to nitrogen drag in the bubbling system, besides the occurrence of the glass effect which is associated with the

Table 1. Conversion, average diameter of the monomer droplets (initial Dp) and polymeric particles (final Dp) and polydispersity index for polymerizations after $8 \mathrm{~h}$ of reaction.

\begin{tabular}{|c|c|c|c|c|c|c|c|}
\hline Entry & Catalyst & $\mathrm{T}\left({ }^{\circ} \mathrm{C}\right)$ & Conversion (\%) & Initial Dp (nm) & Initial PdI & Final Dp (nm) & Final PdI \\
\hline $1^{\mathrm{a}}$ & Blank & 85 & $29.1 \pm 10.2$ & $138.4 \pm 0.99$ & $0.135 \pm 0.042$ & $172.6 \pm 11.6$ & $0.039 \pm 0.051$ \\
\hline 2 & $\mathrm{BMI} \cdot \mathrm{Fe}_{2} \mathrm{Cl}_{7}$ & 85 & $80.8 \pm 4.0$ & $138.6 \pm 10.3$ & $0.086 \pm 0.007$ & $168.5 \pm 7.3$ & $0.030 \pm 0.012$ \\
\hline 3 & & 70 & $23.3 \pm 8.2$ & $162.3 \pm 19.5$ & $0.075 \pm 0.020$ & $152.9 \pm 17.4$ & $0.099 \pm 0.029$ \\
\hline 4 & & 55 & $7.0 \pm 1.9$ & $141.1 \pm 11.0$ & $0.109 \pm 0.025$ & $147.3 \pm 10.2$ & $0.077 \pm 0.039$ \\
\hline 5 & $\mathrm{MAI} \cdot \mathrm{Fe}_{2} \mathrm{Cl}_{7}$ & 85 & $77.3 \pm 2.5$ & $175.2 \pm 20.4$ & $0.039 \pm 0.019$ & $187.9 \pm 9.48$ & $0.009 \pm 0.006$ \\
\hline 6 & & 70 & $21.8 \pm 7.4$ & $157.1 \pm 11.1$ & $0.098 \pm 0.037$ & $135.9 \pm 19.8$ & $0.094 \pm 0.015$ \\
\hline 7 & & 55 & $7.7 \pm 1.4$ & $168.0 \pm 3.0$ & $0.063 \pm 0.022$ & $160.0 \pm 3.2$ & $0.090 \pm 0.034$ \\
\hline $8^{b}$ & $\mathrm{bMIE} \cdot 2 \mathrm{Fe}_{2} \mathrm{Cl}_{7}$ & 85 & 90.8 & 136.5 & 0.145 & 136.7 & 0.037 \\
\hline 9 & & 70 & $21.1 \pm 4.8$ & $159.1 \pm 18.2$ & $0.102 \pm 0.037$ & $158.7 \pm 7.6$ & $0.095 \pm 0.022$ \\
\hline 10 & & 55 & $14.9 \pm 1.6$ & $171.2 \pm 2.9$ & $0.076 \pm 0.014$ & $158.8 \pm 1.41$ & $0.104 \pm 0.038$ \\
\hline $11^{\mathrm{b}, \mathrm{c}}$ & & 85 & 63.9 & 138.5 & 0.099 & 190.3 & 0.021 \\
\hline $12^{\mathrm{b}, \mathrm{d}}$ & $\mathrm{BMI} \cdot \mathrm{Fe}_{2} \mathrm{Cl}_{7}$ & 60 & 71.6 & 137.5 & 0.037 & 182.2 & 0.057 \\
\hline $13^{\mathrm{b}, \mathrm{d}}$ & & 50 & 33.2 & 144.5 & 0.093 & 162.7 & 0.017 \\
\hline $14^{\mathrm{a}, \mathrm{d}}$ & Blank & 60 & $17.9 \pm 4.0$ & $147.4 \pm 5.0$ & $0.121 \pm 0.001$ & $166.5 \pm 3.6$ & $0.023 \pm 0.016$ \\
\hline $15^{\mathrm{b}, \mathrm{e}, \mathrm{f}}$ & $\mathrm{BMI} \cdot \mathrm{Fe}_{2} \mathrm{Cl}_{7}$ & 70 & 0.4 & - & - & - & - \\
\hline $16^{\mathrm{b}, \mathrm{e}, \mathrm{g}}$ & & 70 & 1.7 & - & - & - & - \\
\hline $17^{\mathrm{b}, \mathrm{e}, \mathrm{h}}$ & & 70 & 0.0 & - & - & - & - \\
\hline $18^{\mathrm{b}, \mathrm{e}, \mathrm{i}}$ & & 70 & 71 & - & - & - & - \\
\hline $19^{\mathrm{b}, \mathrm{e}, \mathrm{j}}$ & & 30 & 68.0 & - & - & - & - \\
\hline $20^{\mathrm{b}, \mathrm{e}, \mathrm{k}}$ & & 0 & 9.9 & - & - & - & - \\
\hline
\end{tabular}

${ }^{\mathrm{a}}$ Duplicate syntheses and ${ }^{\mathrm{b}}$ only 1 experimental run. ${ }^{\mathrm{c}}$ Synthesis using unpurified styrene. ${ }^{\mathrm{d}} 24 \mathrm{~h}$ of reaction. ${ }^{\mathrm{e}}$ Bulk polymerization - experimental conditions: $\mathrm{BMI} \cdot \mathrm{Fe}_{2} \mathrm{Cl}_{7} /$ monomer molar ratio of $1: 1000$ and $6 \mathrm{~h}$ of synthesis, using ${ }^{\mathrm{f}}$ methyl methacrylate, ${ }^{\mathrm{g}}$ vinyl pivalate, ${ }^{\mathrm{h}}$ butyl acrylate and styrene at ${ }^{\mathrm{i}} 15 \mathrm{~min}^{[31]},{ }^{\mathrm{j}} 3 \mathrm{~h}$ and ${ }^{\mathrm{k}} 6 \mathrm{~h}$ of reactions. 


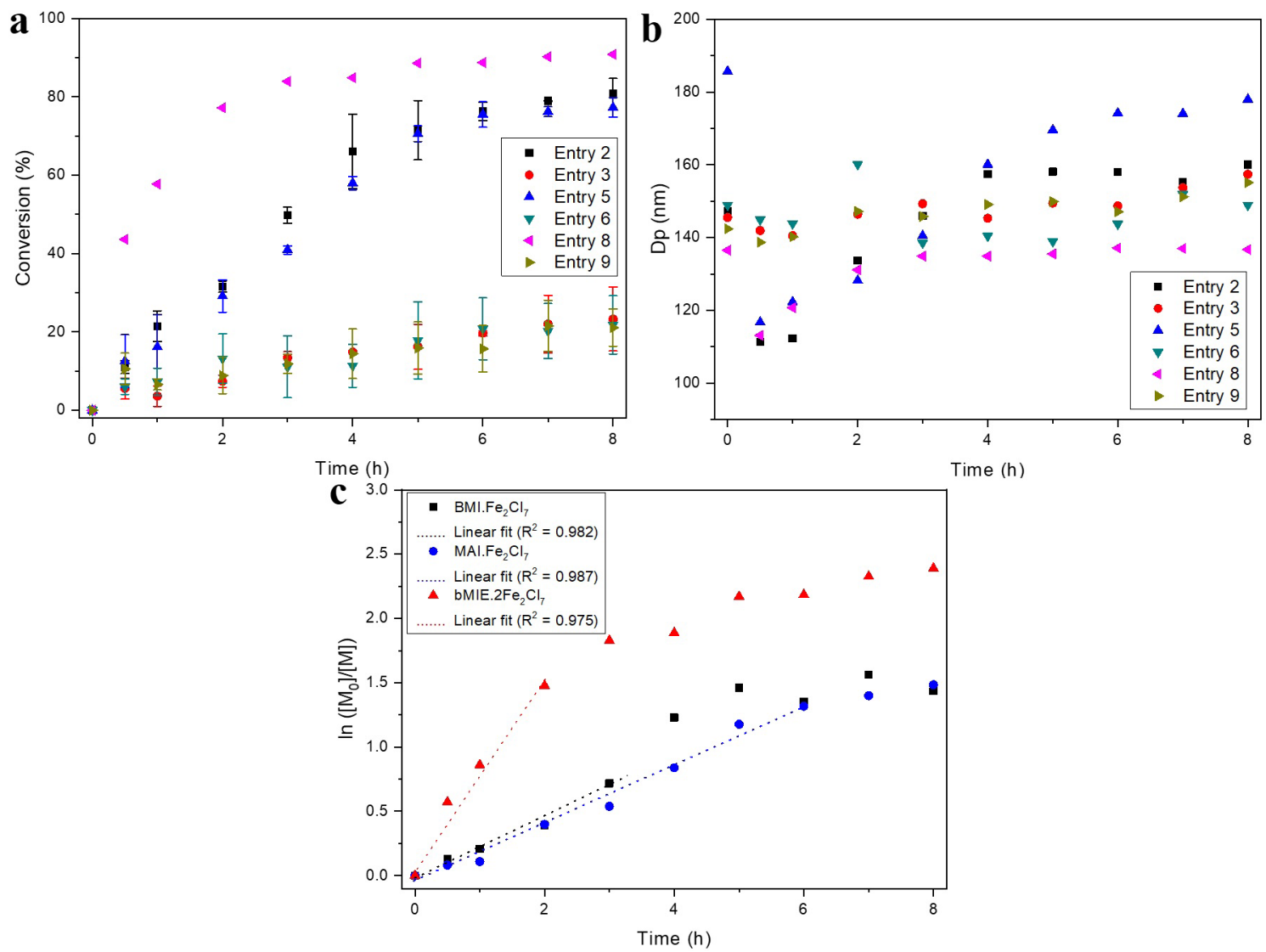

Figure 1. Evolution of (a) conversion; (b) mean diameter of latex particles during reactions at 85 and $70{ }^{\circ} \mathrm{C}$ and; (c) dependence of semilogarithmic of the monomer concentration with synthesis time at $85^{\circ} \mathrm{C}$.

increase of viscosity inside the monomer droplets, leading to a reduction of the reaction rates $^{[32]}$.

The polymerizations were performed at different temperatures of 55,70 and $85^{\circ} \mathrm{C}$ with catalyst/monomer molar ratio of $1: 1000$. For $\mathrm{BMI} \cdot \mathrm{Fe}_{2} \mathrm{Cl}_{7}$, the conversions increased from $7 \%$ to $81 \%$ (Table 1 and Figure 1a) when synthesis temperatures were increased from 55 to $85^{\circ} \mathrm{C}$. Similar behavior was observed for $\mathrm{MAI} \cdot \mathrm{Fe}_{2} \mathrm{Cl}_{7}$ with an increase from $8 \%$ to $77 \%$, whereas for bMIE. $2 \mathrm{Fe}_{2} \mathrm{Cl}_{7}$, it was observed an increase in the conversion from $15 \%$ to $90 \%$. This is because catalytic species become more reactive at higher temperatures ${ }^{[33]}$.

In order to evaluate if competitive thermal polymerization via radical initiation is favored by the reaction temperature $\left(85^{\circ} \mathrm{C}\right)$, a blank reaction was performed under the same experimental conditions, but without the addition of ILs or any other initiator (Entry 1, Table 1). This blank reaction presented a much lower conversion, about $30 \%$. In addition, average molar masses are relatively different from those obtained by using ILs catalysts. Also, under the same experimental conditions, polymerization was carried out in the presence of $\mathrm{BMI} \cdot \mathrm{Fe}_{2} \mathrm{Cl}_{7}$ and radical polymerization inhibitors, as the synthesis was performed with unpurified styrene containing approximately $50 \mathrm{ppm}$ of 4-tert-butylcatechol as stabilizer (Entry 11, Table 1). This reaction presented a relatively high conversion, about $64 \%$ and molar masses very close to those obtained using $\mathrm{BMI} \cdot \mathrm{Fe}_{2} \mathrm{Cl}_{7}$ with purified styrene. Although these reactions were conducted at relatively high temperatures, which might favor the self-initiation of styrene, the polymerizations carried out in presence of ILs catalysts are favorably governed by the cationic route due to the extremely high reactivity of the ILs catalysts.

The effect of temperature was also investigated at $24 \mathrm{~h}$ of reaction, and the results can be observed in Entries 12-14 of Table 1. Again, a low monomer conversion is observed for the blank reactions, around $18 \%$ at $60{ }^{\circ} \mathrm{C}$ (Entry 14, Table 1). On the other hand, the polymerization carried out in the presence of $\mathrm{BMI} \cdot \mathrm{Fe}_{2} \mathrm{Cl}_{7}$ (Entry 12, Table 1) showed conversion of $72 \%$ and even when reactions where conducted at lower temperature of $50{ }^{\circ} \mathrm{C}$, polystyrene is formed, with conversion of $33 \%$ (Entry 13, Table 1) and molar masses quite different from that obtained in the blank reaction. In addition, the decrease in temperature favored the formation of polystyrene with higher number-average molar mass and with narrower dispersity.

As a matter of fact, the above-mentioned results suggest that cationic polymerization is undoubtedly taking place. Additionally, experiments were carried out to verify the ability of other vinyl monomers [methyl methacrylate (MMA), vinyl pivalate (VPi) and butyl acrylate (BuA)] to polymerize via bulk polymerization using $\mathrm{BMI} \cdot \mathrm{Fe}_{2} \mathrm{Cl}_{7}$ at $70{ }^{\circ} \mathrm{C}$ (Entries 15-17, Table 1). It is well-known that these 
monomers cannot be polymerized in accordance with the cationic mechanism due to the instability of the formed carbocation and, therefore, the absence of polymerization gives more evidence that the reaction mechanism is purely cationic. Figure S8 (Supporting Information) presents the ${ }^{1} \mathrm{H}-\mathrm{NMR}$ spectrum of the experiment in which VPi was added (Entry 16, Table 1) and the absence of a signal at $1.7 \mathrm{ppm}$, attributed to methylene $\left(-\mathrm{CH}_{2}-\right)$ protons in the polymer backbone ${ }^{[34]}$, indicating that poly(vinyl pivalate) was not synthesized.

In comparison, experiment using only styrene (Entry 18 , Table 1), led to a rapid polymerization, forming a highly viscous solution in only $15 \mathrm{~min}$, which is highly unlikely to happen through self-initiated thermal polymerization of styrene. Polymerization also succeeded at lower temperatures, as for instance, $i) 30{ }^{\circ} \mathrm{C}$ (Entry 19, Table 1), occurring more slowly and achieving similar conversion after $3 \mathrm{~h}$ and ii) $0{ }^{\circ} \mathrm{C}$, achieving a $9.9 \%$ conversion in $6 \mathrm{~h}$ of reaction (Entry 20, Table 1), which clearly indicates that the polymerization of styrene mediated by this kind of catalyst follows predominantly a cationic mechanism.

These experimental results agree very well with the one described by Alves and coauthors ${ }^{[22]}$, in which replacing ILs catalysts with benzoyl peroxide, conversion around $30 \%$ has been achieved, after $5 \mathrm{~h}$, under the same operating conditions. One should also bear in mind that in the particular case of the ILs catalysts used here, styrene homopolymerization takes place due to the formation of a key styrene chloronium cation, which is believed to be stabilized by the catalyst through ion-pairing effects ${ }^{[31]}$.

Bulk polymerizations (Entry 18, Table 1) ${ }^{[31]}$ achieved limit conversions in much shorter reaction times than miniemulsion polymerizations. This difference can be attributed to the high water content of the miniemulsion system, leading to a reduced reaction rate and thus decreasing conversion. Generally, one of the main obstacles of cationic polymerization has been the high reaction rates that make polymerization control difficult. Thus, the water effect resulted in lower rates, allowing better control of polymerization ${ }^{[22]}$.

It was observed that the mean particle diameter (Dp) remained practically unchanged, as shown in Figure $1 \mathrm{~b}$ and Table S1 of the Supporting Information, that is, the average diameter of the polymeric particles (final Dp) shows values close to the monomer droplets (initial Dp), indicating that nucleation occurs preferentially within the monomeric droplets, and that both effects of coalescence and diffusional degradation were properly minimized during polymerization. Thus, the polymeric latexes were obtained with high colloidal stability and particle diameter between $113 \mathrm{~nm}$ and $197 \mathrm{~nm}$, presenting low polydispersity indexes (PdI) (Table S1, Supporting Information), indicating the formation of polymer nanoparticles with narrow size distribution.

The semilogarithmic plot of monomer concentration versus synthesis time using the ILs catalysts shown in Figure 1c, indicates that polymerization does not follow first-order kinetics throughout the reaction. Kostjuk et al. ${ }^{[35]}$ observed the same behavior when studying cationic polymerization of styrene using $\mathrm{AlCl}_{3}$-based initiators. The authors explained that this curvature (similar to the one depicted in
Figure 1c indicates that the concentration of propagating and reversibly terminated chains decreases more rapidly than the formation of new chains by slow initiation. Theoretically, for a truly living polymerization system, this plot should be linear. Thus, a more detailed analysis shows a linear dependence of the semilogarithmic plot up to a certain polymerization period, indicating that the reactions follow a first-order kinetic up to a limit conversion of about $51 \%$ $\left(\mathrm{BMI} \cdot \mathrm{Fe}_{2} \mathrm{Cl}_{7}\right), 73 \%\left(\mathrm{MAI} \cdot \mathrm{Fe}_{2} \mathrm{Cl}_{7}\right)$ and $77 \%\left(\mathrm{bMIE} \cdot 2 \mathrm{Fe}_{2} \mathrm{Cl}_{7}\right)$. Semilogarithmic linear dependence has been reported up to a $51 \%$ conversion $^{[36]}$ and a $23 \%$ conversion $^{[37]}$ in the cationic polymerization of $\alpha$-methylstyrene using $\mathrm{FeCl}_{3}$ based initiators and in the reaction of a peptide-poly(methyl methacrylate) (peptide-PMMA) hybrid bioconjugates by atom transfer radical polymerization (ATRP), respectively. Therefore, polymerization systems using ILs catalysts are possibly cationic in nature, following a first-order kinetics to a limit conversion.

Figure 2 shows the molar mass distribution curves of the polystyrenes obtained as a function of conversion using the different ILs catalysts at $85^{\circ} \mathrm{C}$, these values are shown in Table S2 in the Supporting Information. It was possible to synthesize polystyrene with high number-average molar mass, around $1300 \mathrm{~kg} \mathrm{~mol}^{-1}$, much higher than those obtained by Cauvin et al. ${ }^{[8,11]}$ and Touchard et al. ${ }^{\left[{ }^{[9}\right.}$ who studied the cationic miniemulsion polymerization of $p$-methoxystyrene, obtaining $\bar{M}_{n}$ between $1.0-39.4 \mathrm{~kg} \mathrm{~mol}^{-1}$. These results are indicative that the polymerization mechanism occurs preferably inside monomer droplets rather than at the monomer droplets/water interface, commonly obtained in miniemulsion ionic polymerizations ${ }^{[5,8,9,11]}$.

Table S2 in the Supporting Information shows the average molar masses and $\bigoplus_{M}$ of the polystyrenes obtained in bulk polymerization (shown in Entries 18-20, Table 1). These polymers had number-average molar mass, $\bar{M}_{n}$ around $15 \mathrm{~kg} \mathrm{~mol}^{-1}$, much lower than those achieved by miniemulsion polymerization. These differences can be attributed to the characteristics of the two synthesis processes, since in the bulk polymerization there is an increase in viscosity as the conversion increases, causing the interruption of the homogenization of the system and delaying the mobility of the monomer to the growing chains. In addition, there is a much higher concentration of reactive species at the bulk polymerization locus, resulting in lower molar masses ${ }^{[22]}$.

The values of the average molar masses of polystyrene obtained after $8 \mathrm{~h}$ of synthesis showed significant differences when using different ILs catalysts, and the polymers obtained in the presence of bMIE. $2 \mathrm{Fe}_{2} \mathrm{Cl}_{7}$ showed the lowest numberaverage molar mass. This difference is attributed to the higher concentration of the catalytic species, $\mathrm{Fe}_{2} \mathrm{Cl}_{7}$, in the polymerization locus. As a result, the initiation step is favored, resulting in the formation of several polymer chains with smaller molar mass (less than $800 \mathrm{~kg} \mathrm{~mol}^{-1}$ ) and with different sizes, consequently, increasing the molar-mass dispersity (higher than 2.1). The samples obtained with the other catalysts, $\mathrm{BMI} \cdot \mathrm{Fe}_{2} \mathrm{Cl}_{7}$ and $\mathrm{MAI} \cdot \mathrm{Fe}_{2} \mathrm{Cl}_{7}$, presented similar number-average molar mass and molar-mass dispersity, since they have relatively equal concentrations of the catalytic species. These results support the assumption that cationic polymerization takes place, since the increase in the concentration of catalytic species, using bMIE- $2 \mathrm{Fe}_{2} \mathrm{Cl}_{7}$, led a 

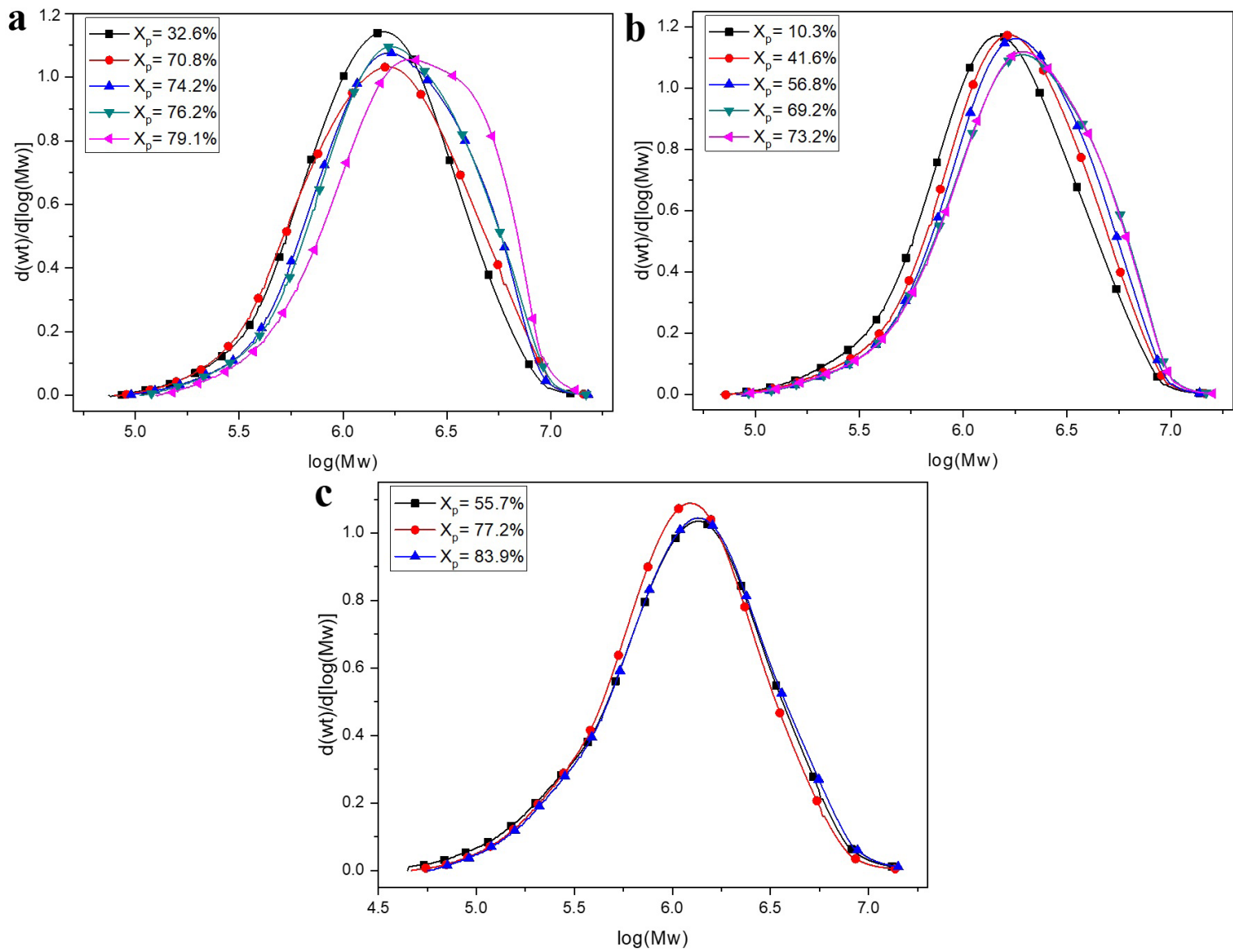

Figure 2. Molar mass distribution curves of the polystyrenes synthesized by using ILs catalysts at $85^{\circ} \mathrm{C}$ (a) $\mathrm{BMI} \cdot \mathrm{Fe}_{2} \mathrm{Cl}_{7} ;$ (b) $\mathrm{MAI} \cdot \mathrm{Fe}_{2} \mathrm{Cl}_{7}$; (c) bMIE $2 \mathrm{Fe}_{2} \mathrm{Cl}_{7}$.

decrease in the molar masses. Rodrigues et al. ${ }^{[31]}$ had already observed a reduction in the average molar masses with the increase in the concentration of the catalyst $\mathrm{BMI} \cdot \mathrm{Fe}_{2} \mathrm{Cl}_{7}$ in the styrene bulk polymerization.

The molar mass distribution curves of the obtained polymers, Figure 2, are unimodal and a slight displacement of the curves is observed for higher average molar masses values as the conversion increases. Nevertheless, under these conditions, molar-mass dispersity remained relatively high $\left(\mathrm{Ð}_{\mathrm{M}} \cong 1.9\right)$ throughout the reaction, suggesting that polymerization is not as well controlled as in other studies ${ }^{[38]}$. However, the samples synthesized here have narrower distribution compared to other studies that exemplified the formation of polymer with high molar mass.

The molar mass distribution curves of the blank reaction performed at $85^{\circ} \mathrm{C}$ (Entry 1 , Table 1), and of the polymerizations in the presence of $\mathrm{BMI} \cdot \mathrm{Fe}_{2} \mathrm{Cl}_{7}$ at $85^{\circ} \mathrm{C}$ with purified (Entry 2, Table 1) and unpurified styrene (Entry 11, Table 1) are shown in Figure 3a. The values of average molar masses and $\bigoplus_{\mathrm{M}}$ are shown in Table S2 (Supporting Information). The blank reaction showed lower molar masses than those obtained using ILs catalysts and the profile of the molar mass distribution curves are relatively different. On the other hand, the molar mass distribution, as well as, the average molar masses using BMI. $\mathrm{Fe}_{2} \mathrm{Cl}_{7}$ with purified and non-purified styrene are very similar.
Figure $3 \mathrm{~b}$ shows the molar mass distribution curves of reactions performed at lower temperatures and $24 \mathrm{~h}$ of reaction, including polymerizations in the presence of $\mathrm{BMI} \cdot \mathrm{Fe}_{2} \mathrm{Cl}_{7}$ at $60{ }^{\circ} \mathrm{C}($ Entry 12 , Table 1$)$ and $50^{\circ} \mathrm{C}$ (Entry 13 , Table 1$)$ and the blank reaction at $60{ }^{\circ} \mathrm{C}$ (Entry 14, Table 1). Table S2 (Supporting Information) shows the values of average molar masses and $\bigoplus_{\mathrm{M}}$. Again, the blank reaction showed lower molar masses than the one observed for the reaction conducted in the presence of the catalyst $\mathrm{BMI} \cdot \mathrm{Fe}_{2} \mathrm{Cl}_{7}$ and the decrease in the synthesis temperature caused a slight increase in the number-average molar mass and a decrease in the molar-mass dispersity. This behavior is characteristic of cationic polymerization.

Figure 4 shows the molar mass distribution of the polystyrenes obtained at different synthesis temperatures. It is noticed that higher average molar masses and narrow dispersions were obtained as temperature is decreased (from $\bar{M}_{n}=1266 \mathrm{~kg} \mathrm{~mol}^{-1}$ and $\bigoplus_{\mathrm{M}}=1.88$ at $85{ }^{\circ} \mathrm{C}$ to $\bar{M}_{n}=1940 \mathrm{~kg} \mathrm{~mol}^{-1}$ and $\mathrm{Ð}_{\mathrm{M}}=1.73$ at $55^{\circ} \mathrm{C}$ using $\mathrm{BMI} \cdot \mathrm{Fe}_{2} \mathrm{Cl}_{7}$ catalyst; see Figure $3 \mathrm{a}$ ). This behavior is typical of cationic polymerization, since they are better controlled at low temperatures, which favors the propagation reactions over the termination reactions, leading to the formation of polymers with higher average molar masses ${ }^{[33]}$.

The observed values for the molar-mass dispersity close to 2 is characteristic of cationic chain polymerizations where 

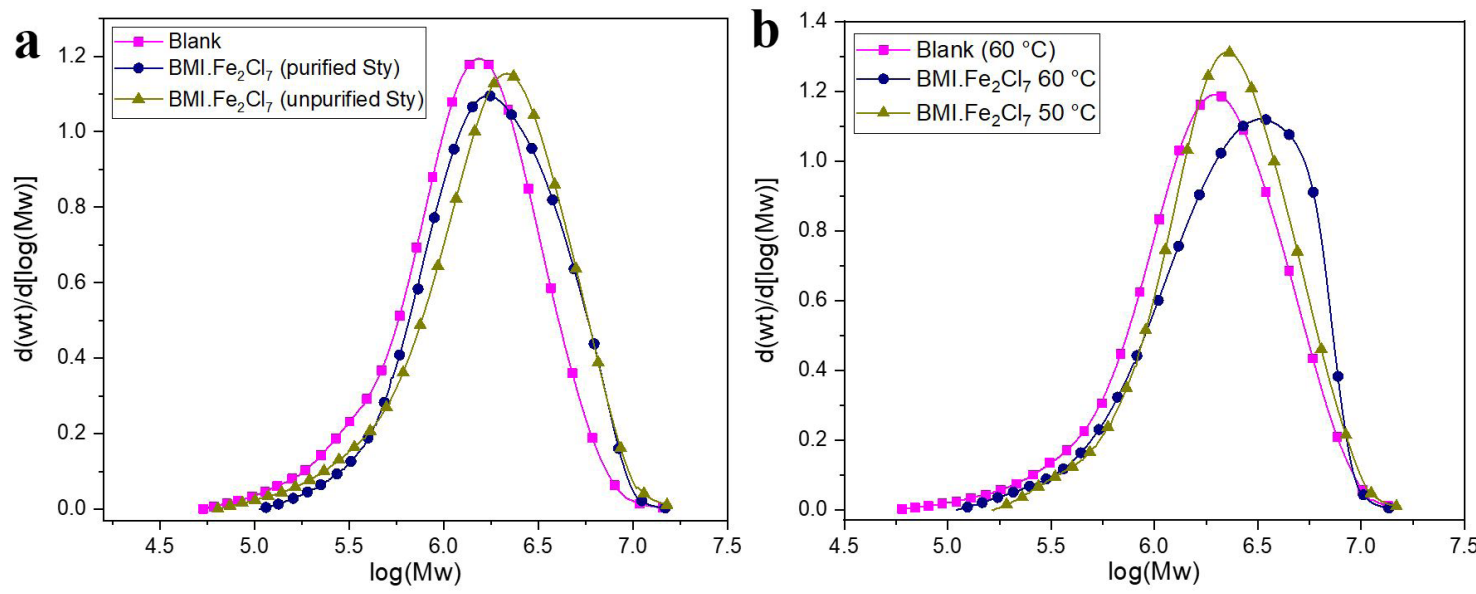

Figure 3. Molar mass distribution curves of the polystyrenes obtained by (a) blank reaction and using $\mathrm{BMI} \cdot \mathrm{Fe}_{2} \mathrm{Cl}_{7}$ in the presence of purified and unpurified styrene at $85{ }^{\circ} \mathrm{C}$ and (b) reactions conducted at 60 and $50{ }^{\circ} \mathrm{C}$ for $24 \mathrm{~h}$.
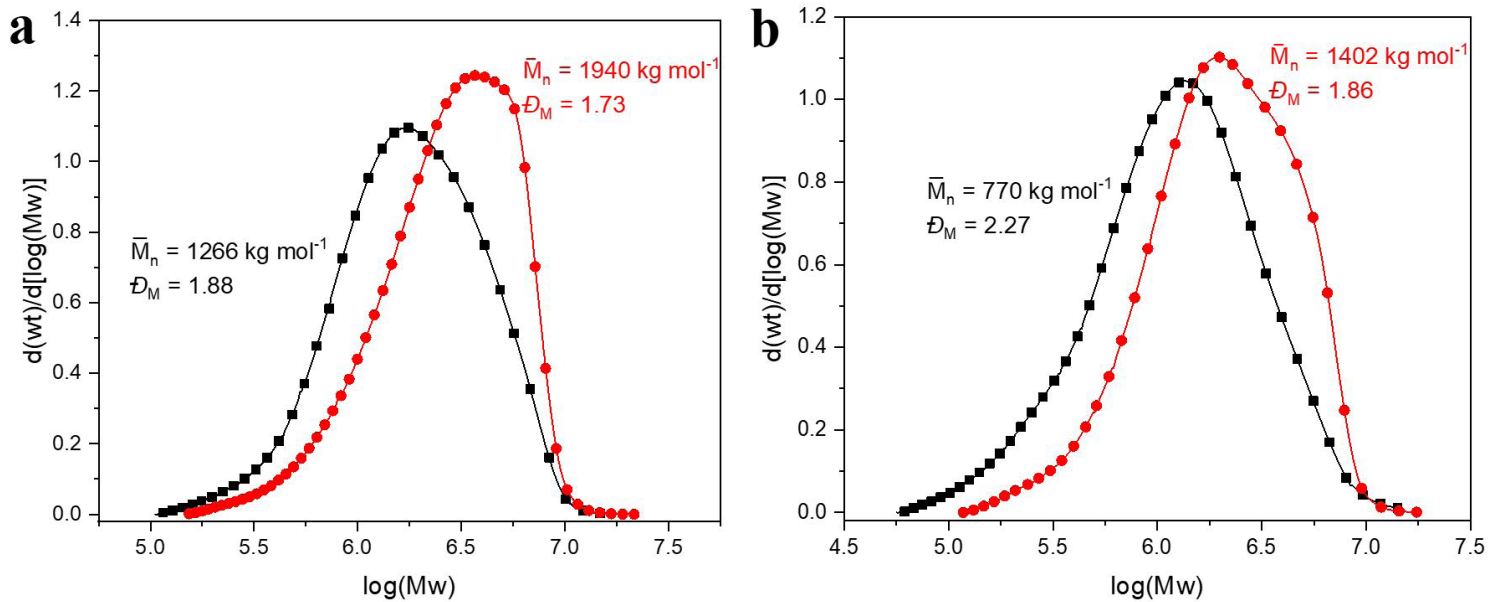

Figure 4. Molar mass distribution curves of polystyrene as a function of the synthesis temperature line and symbol black $\left(85^{\circ} \mathrm{C}\right)$ and red $\left(55^{\circ} \mathrm{C}\right)$ using catalysts (a) $\mathrm{BMI} \cdot \mathrm{Fe}_{2} \mathrm{Cl}_{7}$ and (B) bMIE $2 \mathrm{Fe}_{2} \mathrm{Cl}_{7}$.

termination and transfer reactions are highly expected to take place, mainly when the reaction achieves elevated conversions. Based on this reaction behavior, it is strongly expected to produce polystyrenes exhibiting broad molar mass distributions with $\bigoplus_{\mathrm{M}}$ relatively higher than 2 , reflecting the effect of the reaction operation conditions. As an additional effect, the increase of the local viscosity may also contribute to the occurrence of transfer reactions, accounting for the reduction of the reaction rates, as a result of the decreased migration of the monomer molecules to the active species.

The molar-mass dispersity, in all syntheses, remained higher than 1.8 throughout polymerization. $\mathrm{Ð}_{\mathrm{M}}$ values obtained here were relatively larger than those reported by Touchard et al. ${ }^{[9]}$, Satoh et al. ${ }^{[3]}$, Kostjuk \& Ganachaud ${ }^{[6]}$ and Biedrón \& Kubisa ${ }^{[39]}$ who polymerized $p$-methoxystyrene by miniemulsion, $p$-alkoxystyrenes by emulsion, and styrene by suspension and solution polymerization, respectively, and obtained $\bigoplus_{\mathrm{M}}$ of less than 1.5. However, the molar mass obtained in these studies $\left(\bar{M}_{n} \leq 4.5 \mathrm{~kg} \mathrm{~mol}^{-1}\right)$ were much lower than those reported here. There are reports in the literature of styrene-derived polymers with higher number-average molar mass, $40^{[11]}, 117^{[12]}$, and $550 \mathrm{~kg} \mathrm{~mol}^{-1[40]}$, in which, the distributions are relatively high, from 2.0 to 3.8 , because it is very difficult to control these polymerization mechanism as large polymer chains are formed.

These results are very promising because the other authors who synthesized polystyrene or its derivatives via cationic polymerization in water-based systems (miniemulsion, emulsion or suspension) generally obtained low molar mass and used high synthesis times and excessive catalyst concentration and/or activators ${ }^{[3,6,7,11]}$. For example, Satoh et al..$^{[3]}$ performed cationic emulsion polymerization of $p$-methoxystyrene (pMOS) using pMOS-HCl adduct/lanthanide triflates initiation system. The authors used $[\mathrm{pMOS}]=3.0 \mathrm{M}$; $[\mathrm{pMOS}-\mathrm{HCl}]=60 \mathrm{mM}$; $\left[\mathrm{Yb}(\mathrm{OTf})_{3}\right]=300 \mathrm{mM}$ and obtained a conversion of $78 \%$ after $50 \mathrm{~h}$ of synthesis at $30{ }^{\circ} \mathrm{C}$ and achieved $\bar{M}_{n}=2.38 \mathrm{~kg} \mathrm{~mol}^{-1}$ and $\mathrm{Ð}_{\mathrm{M}}=1.38$. Cauvin et al. ${ }^{[11]}$ used $[\mathrm{pMOS}]=1.5 \mathrm{M}$; [pentachlorophenol $(\mathrm{PCP})]=30 \mathrm{mM} ;\left[\mathrm{Yb}(\mathrm{OTf})_{3}\right]=150 \mathrm{mM}$ and obtained conversion of $67 \%$ in miniemulsion after $400 \mathrm{~h}$ at $60{ }^{\circ} \mathrm{C}$ and reached $\bar{M}_{n}=39.4 \mathrm{~kg} \mathrm{~mol}^{-1}$ and $\bigoplus_{\mathrm{M}}=3.8$. More recently, Zhang et al. ${ }^{[10]}$ obtained conversion of $51 \%$ and $\bar{M}_{n}=3.2 \mathrm{~kg} \mathrm{~mol}^{-1}$ in cationic suspension polymerization 
of styrene initiated by cumyl alcohol $(\mathrm{CumOH}) / \mathrm{B}\left(\mathrm{C}_{6} \mathrm{~F}_{5}\right)_{3}$, using the following experimental conditions: $[\mathrm{St}]=1.75 \mathrm{M}$; $[\mathrm{CumOH}]=0.05 \mathrm{M} ;\left[\mathrm{B}\left(\mathrm{C}_{6} \mathrm{~F}_{5}\right)_{3}\right]=0.05 \mathrm{M}$ at $20^{\circ} \mathrm{C}$ and $50 \mathrm{~h}$ of synthesis. Therefore, our process enables cost savings, leading to reagent savings, low catalyst concentration, while also avoiding the use of rare earth catalysts such as ytterbium triftalates, and relatively shorter synthesis time.

In order to verify the living nature of these polymerizations, a monomer feeding was performed in the miniemulsion previously prepared with $\mathrm{BMI} \cdot \mathrm{Fe}_{2} \mathrm{Cl}_{7}$ at $85^{\circ} \mathrm{C}\left(\mathrm{X}_{\mathrm{p}}=83.0 \%\right.$ Table S1, Supporting Information, $\vec{M}_{n}=989 \mathrm{~kg} \mathrm{~mol}^{-1}$ and $\left.\mathrm{Ð}_{\mathrm{M}}=1.65\right)$. In this experiment $1 \%(\mathrm{w} / \mathrm{w})$ styrene was added to the total, and the reaction was kept under magnetic stirring at $800 \mathrm{rpm}$ at $70{ }^{\circ} \mathrm{C}$ for $4 \mathrm{~h}$. The molar mass distribution curves are shown in Figure 5.

This styrene feeding caused a system destabilization, being observed the formation of two phases, a dark clot in less quantity $\left(\mathrm{X}_{\mathrm{p}}=84.7 \%\right)$ and a stable latex phase $\left(\mathrm{X}_{\mathrm{p}}=82.5 \%\right)$. The molar mass distribution curve of the clot exhibited a broad signal, with marked displacement towards higher molar masses, showing $\bar{M}_{n}=1163 \mathrm{~kg} \mathrm{~mol}^{-1}$ and $\bigoplus_{M}=1.82$. According to Banerjee et al. ${ }^{[41]}$ the increase in molar mass distribution after monomer feeding is due to the slow initiation and slow exchange between reversibly terminated and propagating species. Regarding the obtained stable latex phase (Figure 5c), a change in the distribution curves was observed, leading to a reduction in the average molar mass and a narrow distribution, indicating that the polymeric chains present in dispersion were more monodisperse. This behavior and experimental data from Figure 1c may suggest a certain livingness of the reactive

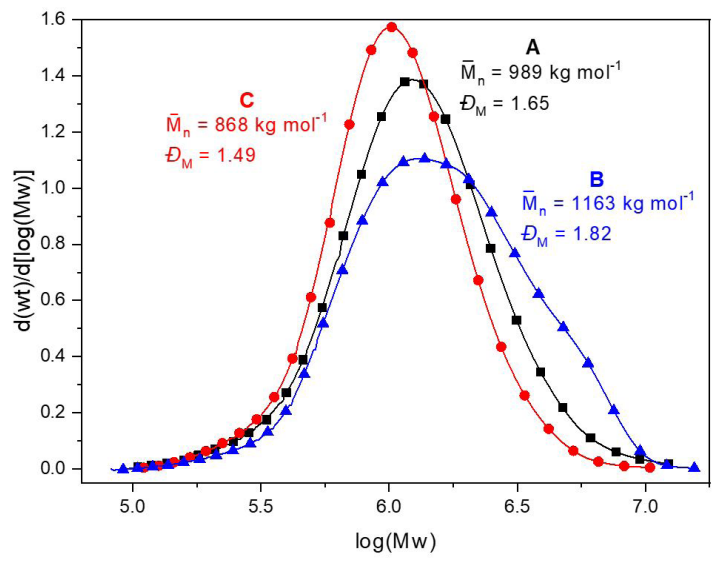

Figure 5. Molar mass distribution curves of polystyrene from the monomer feeding experiment (A) before feeding and after feeding: (B) clot and (C) stable latex phase. species, however the styrene polymerization with the IL catalyst evaluated here cannot be considered as a living polymerization in its strict sense, due to destabilization of cationic propagating species at the reaction temperature.

The glass transition temperature $\left(T_{\mathrm{g}}\right)$ values of the purified and unpurified polymers were determined through the DSC curves and are presented in Table 2 . In this work, $T_{\mathrm{g}}$ values of unpurified polymers were determined in the range from $87^{\circ} \mathrm{C}$ to $95^{\circ} \mathrm{C}$, depending on the type of catalyst used. Samples with higher molar mass presented higher $T_{\mathrm{g}}$ values, due to reduced mobility of polymeric chains. The blank reaction (performed in the absence of catalyst) showed a $T_{\mathrm{g}}$ value close to the unpurified polymer, around $96^{\circ} \mathrm{C}$. On the other hand, the $T_{\mathrm{g}}$ values of purified polymers were determined in the range from $102{ }^{\circ} \mathrm{C}$ to $108^{\circ} \mathrm{C}$, depending on the amount of hexadecane present in the polymeric materials.

$T_{\mathrm{g}}$ values obtained for the purified polymers are similar to the polystyrene samples reported in the literature $\left(107 \pm 2{ }^{\circ} \mathrm{C}\right)^{[42,43]}$ that presented high average molar mass. The increase in $T_{\mathrm{g}}$ values above $15^{\circ} \mathrm{C}$ after purification of the polymers is due to the hexadecane removal occurred during the drying process with dichloromethane and cannot be associated to very small amount of ILs catalysts used in the polymerizations. The evidences supporting this hypothesis are: $\boldsymbol{i})$ very low molar concentration of catalysts, around $0.4 \%$; ii) blank reaction (without the addition of ILs) with low $\mathrm{T}_{\mathrm{g}}$, around $96^{\circ} \mathrm{C}$; and iii) reduction of the hexadecane content in the polymeric structure calculated by relative integration method of the spectrum of ${ }^{1} \mathrm{H}-\mathrm{NMR}^{[44]}$ (Figure S9 of the Supporting Information).

The co-stabilizer, hexadecane, used to prevent Ostwald ripening, may act as a plasticizer due to its extremely low volatility, remaining in the polymeric structure, causing a reduction in intermolecular forces between chains, increasing molecular mobility and consequently reducing $T_{\mathrm{g}}$. Recently, polystyrene with $T_{\mathrm{g}}=90.1^{\circ} \mathrm{C}$ was obtained by miniemulsion polymerization containing 4 wt. $\%$ of hexadecane ${ }^{[45]}$. Christie et al. ${ }^{[46]}$ observed the same effect using glycerol suspended polystyrene films and Shen et al. ${ }^{[47]}$ reported that hexadecane dispersed in the polyacrylate matrix caused a significant reduction in $\mathrm{T}_{\mathrm{g}}$, decreasing from $6.38^{\circ} \mathrm{C}$ (emulsion) to $3.92{ }^{\circ} \mathrm{C}$ (miniemulsion).

In addition, the plasticizing effect of residual catalyst can be ruled out, since the molar ratio used is very low in relation to the polymeric fraction obtained and in a previous study low $\mathrm{T}_{\mathrm{g}}$ values (up to $88^{\circ} \mathrm{C}$ with $\bar{M}_{n}=183 \mathrm{~kg} \mathrm{~mol}^{-1}$ ) were obtained after the polystyrene purification ${ }^{[31]}$. The formation of branched polystyrene can also be phased out, because these polymers have $T_{g}$ and molar masses much lower than those obtained here ${ }^{[39-42][48-51]}$ and the formation of branching favors a significant increase of $\bar{M}_{w}$ and molar-

Table 2. Average molar masses, molar-mass dispersity and glass transition temperature $\left(_{\mathrm{g}}\right)$ of the polymers synthesized at $85^{\circ} \mathrm{C}$ using ILs catalysts and blank polymerization.

\begin{tabular}{|c|c|c|c|c|c|c|c|c|}
\hline Entry & Catalyst & $\mathrm{T}\left({ }^{\circ} \mathrm{C}\right)$ & $\bar{M}_{w}\left(\mathrm{~kg} \mathrm{~mol}^{-1}\right)$ & $\bar{M}_{n}\left(\mathrm{~kg} \mathrm{~mol}^{-1}\right)$ & $\mathbf{D}_{\mathrm{M}}$ & $T_{g}\left({ }^{\circ} C\right)^{\mathrm{a}}$ & $T_{g}\left({ }^{\circ} C\right)^{\mathrm{b}}$ & HD (\%) \\
\hline 1 & Blank & 85 & 1821 & 891 & 2.04 & 95.8 & & \\
\hline 2 & $\mathrm{BMI} \cdot \mathrm{Fe}_{2} \mathrm{Cl}_{7}$ & 85 & 2375 & 1266 & 1.88 & 93.6 & 108.1 & 1.6 \\
\hline 3 & $\mathrm{MAI} \cdot \mathrm{Fe}_{2} \mathrm{Cl}_{7}$ & 85 & 2526 & 1306 & 1.93 & 94.5 & 102.8 & 3.1 \\
\hline 4 & $\mathrm{bMIE} \cdot 2 \mathrm{Fe}_{2} \mathrm{Cl}_{7}$ & 85 & 1749 & 770 & 2.27 & 87.7 & 106.6 & 2.0 \\
\hline
\end{tabular}

${ }^{\mathrm{a}}$ before and ${ }^{\mathrm{b}}$ after purification. ${ }^{\mathrm{c}}$ hexadecane content after purification of the polymers, calculated by the relative integration method. 
mass dispersity with an increase in conversion ${ }^{[48,51]}$, which did not occur in our work (Table S2, Supporting Information).

In addition, the polystyrene tacticity after purification was determined by integrating the signals between 144147 ppm of the ${ }^{13} \mathrm{C}$-NMR spectra (Figure S10, Supporting Information). On the basis of isotactic ( $\mathrm{mm})$, atactic (mr) and syndiotactic (rr) triads assignments, syndiotactic polystyrenes were obtained, consisting essentially of around $10 \%$ isotactic, $20 \%$ atactic and $70 \%$ syndiotactic configurations.

The micrographs (Figure 6) and the size distribution histograms (Figure 7) show the formation of particles of nanometer size, relatively uniform in size and shape, being spherical and having an average size of $119.6 \pm$ $23.3 \mathrm{~nm}\left(\mathrm{BMI} \cdot \mathrm{Fe}_{2} \mathrm{Cl}_{7}\right), 153.5 \pm 37.3 \mathrm{~nm}\left(\mathrm{MAI} \cdot \mathrm{Fe}_{2} \mathrm{Cl}_{7}\right)$ and $116.7 \pm 15.2 \mathrm{~nm}\left(\mathrm{bMIE} \cdot 2 \mathrm{Fe}_{2} \mathrm{Cl}_{7}\right)$. The average size estimated by TEM is slightly smaller than the hydrodynamic size obtained by DLS, approximately $30 \mathrm{~nm}$ smaller (Entries 2,5 and 8 of Table 1). This difference is explained by the fact that the techniques are performed under completely different conditions. The DLS measures the Brownian motion of aqueous dispersion and relates them to the diameter of the particles, which may be affected by the swelling of the polymeric shell, causing an increase in the average particle size. While TEM analysis the sample is dried on a film and exposed to electron beam, probably promoting shrinking phenomena ${ }^{[52]}$. In addition, the average particle size computed based on TEM images refers to the number-average, whereas DLS determines the intensity average particle size that provides a higher weight to the bigger particles.

It is also observed, in all micrographs, the presence of some smaller nanoparticles, with undefined shapes and
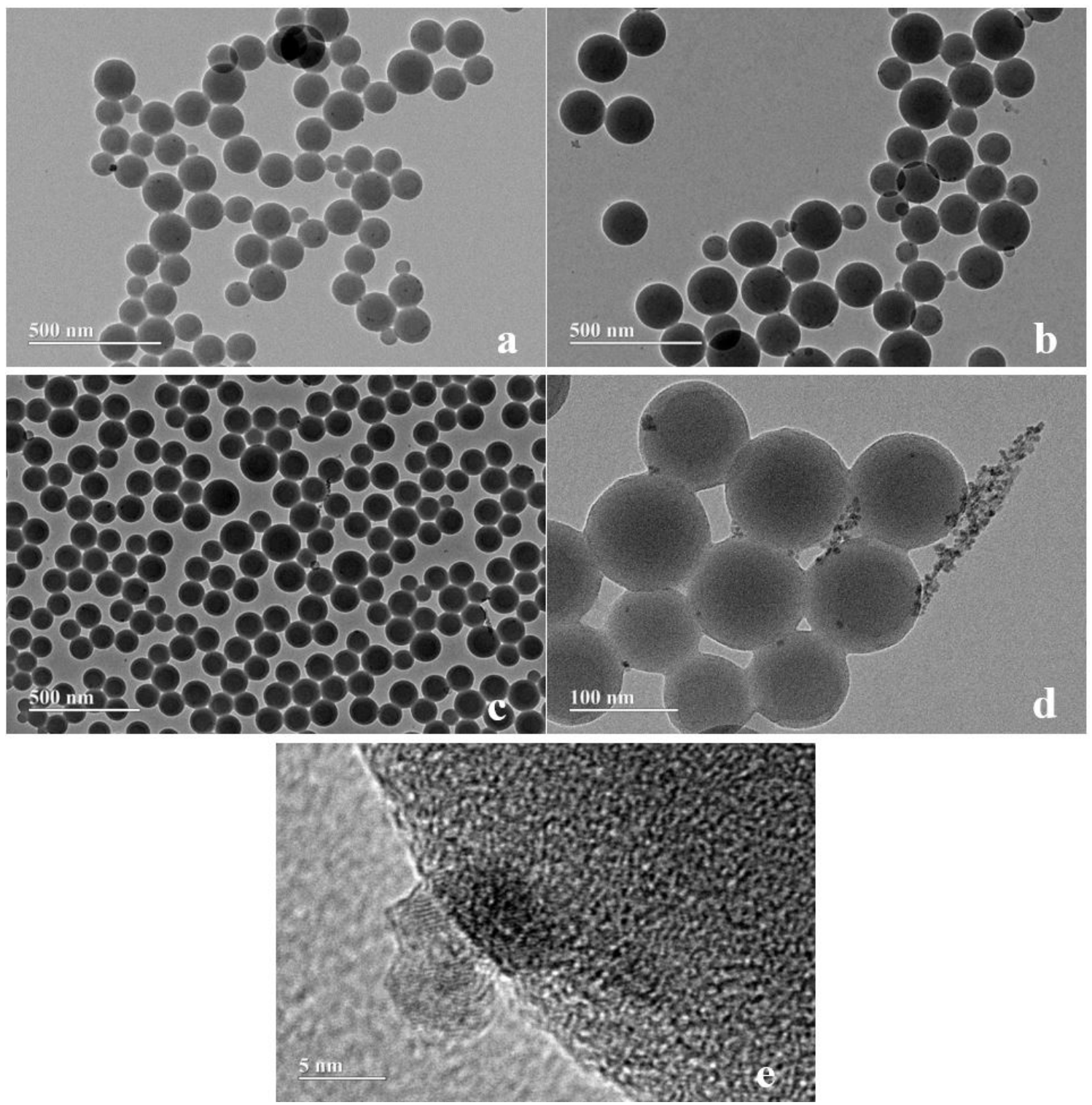

Figure 6. TEM micrographs of unpurified polystyrene samples synthesized with catalysts (a) $\mathrm{BMI}_{\mathrm{Fe}} \mathrm{Cl}_{7} ;$ (b) $\mathrm{MAI} \cdot \mathrm{Fe}_{2} \mathrm{Cl}_{7}$ and (c) bMIE. $2 \mathrm{Fe}_{2} \mathrm{Cl}_{7}$ at $85^{\circ} \mathrm{C}$; (d) presence of bMIE. $2 \mathrm{Fe}_{2} \mathrm{Cl}_{7}$ catalyst and (e) crystalline plane observed in the sample with $\mathrm{BMI} \cdot \mathrm{Fe}_{2} \mathrm{Cl}_{7}$. 

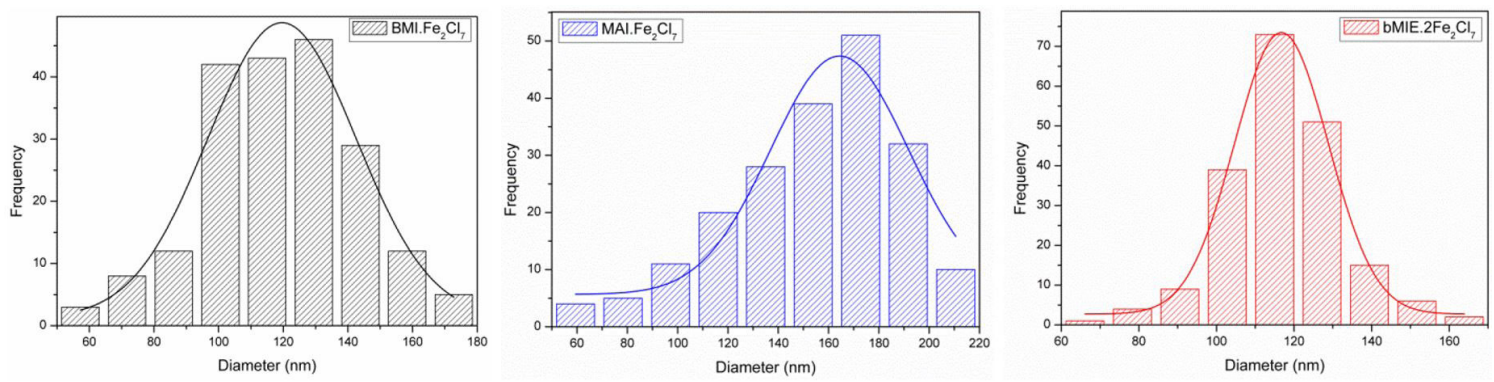

Figure 7. Size distribution histograms of polystyrene synthesized with ILs catalysts at $85{ }^{\circ} \mathrm{C}$ obtained from TEM analysis.

sizes below $10 \mathrm{~nm}$, being also present inside the spherical polystyrene particles (Figure 6d). The presence of crystalline planes (Figure 6e) indicates that ILs catalysts are contained in the polymeric matrix. This corroborates that polymerization occurs within the monomer droplets and with the reduction in $T_{\mathrm{g}}$ previously reported.

\section{Conclusions}

The use of iron-containing ILs catalysts has been shown to be very effective in styrene miniemulsion polymerization, achieving high conversions even at low catalyst concentrations. The largest conversions were obtained using the bMIE $2 \mathrm{Fe}_{2} \mathrm{Cl}_{7}$ catalyst and the largest molar masses were achieved in $\mathrm{BMI} \cdot \mathrm{Fe}_{2} \mathrm{Cl}_{7}$ and $\mathrm{MAI} \cdot \mathrm{Fe}_{2} \mathrm{Cl}_{7}$. The size of the polymeric nanoparticles remained practically unchanged during the reactions and high number-average molar masses were obtained (around $1300 \mathrm{~kg} \mathrm{~mol}^{-1}$ ) with molar-mass dispersity of 2.0, indicating that the polymerization mechanism occurred preferentially within the monomer droplets. The cationic polymerization behavior was confirmed by the reduction of the average molar masses with increased concentration of the catalytic species, $\mathrm{Fe}_{2} \mathrm{Cl}_{7}$, and with increasing temperature, by the first-order kinetics until a limit conversion, successful monomer feeding evaluation, obtaining polystyrene at low temperatures and inability to polymerize methyl methacrylate and other monomers not able to be polymerized through a cationic mechanism. Finally, these results are very promising and future work may focus on the application of these catalysts in cationic polymerization in miniemulsion of other vinyl monomers or via ring opening, as well as studying the encapsulation of different materials inside polystyrene nanoparticles.

\section{Acknowledgements}

This work has been supported by CNPq, CAPES - Finance code 001, FINEP, FAPDF and PROCAD Process $n^{\circ} 88881.068432 / 2014-01$. The authors thank the Laboratório Multiusuário de Microscopia de Alta Resolução (LabMic) for the TEM micrographs.

\section{References}

1. Distler, D., Neto, W. S., \& Machado, F. (2017). Emulsion polymerization. In S. Hashmi (Eds.), Reference module in materials science and materials engineering (pp. 1-14). New
York: Elsevier. http://dx.doi.org/10.1016/B978-0-12-8035818.03746-2.

2. Bompart, M., Vergnaud, J., Strub, H., \& Carpentier, J. F. (2011). Indium(III) halides as exceptionally active, watertolerant catalysts for cationic polymerization of styrenics. Polymer Chemistry, 2(8), 1638-1640. http://dx.doi.org/10.1039/ c1py00145k.

3. Satoh, K., Kamigaito, M., \& Sawamoto, M. (2000). Lanthanide triflates-mediated emulsion cationic polymerization of p-alkoxystyrenes in aqueous media. Macromolecules, 33(13), 4660-4666. http://dx.doi.org/10.1021/ma0000069.

4. Maitre, C., Ganachaud, F., Ferreira, O., Lutz, J. F., Paintoux, Y., \& Hémery, P. (2000). Anionic polymerization of phenyl glycidyl ether in miniemulsion. Macromolecules, 33(21), 7730-7736. http://dx.doi.org/10.1021/ma0007132.

5. Kostjuk, S. V., \& Ganachaud, F. (2010). Cationic polymerization of vinyl monomers in aqueous media: from monofunctional oligomers to long-lived polymer chains. Accounts of Chemical Research, 43(3), 357-367. http://dx.doi.org/10.1021/ar900198q. PMid:19957949.

6. Kostjuk, S. V., \& Ganachaud, F. (2006). Cationic polymerization of styrene in solution and aqueous suspension using $\mathrm{B}(\mathrm{C} 6 \mathrm{~F} 5) 3$ as a water-tolerant Lewis acid. Macromolecules, 39(9), 31103113. http://dx.doi.org/10.1021/ma052650z.

7. Vasilenko, I. V., Ganachaud, F., \& Kostjuk, S. V. (2016). New insights into the cationic polymerization in emulsion catalyzed by water-dispersible Lewis acid surfactant complexes: a case study with $p$-methoxystyrene. Macromolecules, 49(9), 32643273. http://dx.doi.org/10.1021/acs.macromol.6b00379.

8. Cauvin, S., Sadoun, A., Dos Santos, R., Belleney, J., Ganachaud, F., \& Hemery, P. (2002). Cationic polymerization of $p$-methoxystyrene in miniemulsion. Macromolecules, 35(21), 7919-7927. http://dx.doi.org/10.1021/ma0202890.

9. Touchard, V., Graillat, C., Boisson, C., D’Agosto, F., \& Spitz, R. (2004). Use of a Lewis acid surfactant combined catalyst in cationic polymerization in miniemulsion: Apparent and hidden initiators. Macromolecules, 37(9), 3136-3142. http:// dx.doi.org/10.1021/ma0355352.

10. Zhang, J., Wu, Y., Li, X., Yang, D., Zhang, M., Wang, H., Shang, Y., Ren, P., Mu, X., Li, S., \& Guo, W. (2019). Characteristics and mechanism of styrene cationic polymerization in aqueous media initiated by cumyl alcohol/B(C6F5)3. Macromolecular Chemistry and Physics, 220(4), 1800419-1800427. http:// dx.doi.org/10.1002/macp.201800419.

11. Cauvin, S., Ganachaud, F., Moreau, M., \& Hémery, P. (2005). High molar mass polymers by cationic polymerisation in emulsion and miniemulsion. Chemical Communications, (21), 2713-2715. http://dx.doi.org/10.1039/b501489a. PMid:15917929.

12. Vasilenko, I. V., Yeong, H. Y., Delgado, M., Ouardad, S., Peruch, F., Voit, B., Ganachaud, F., \& Kostjuk, S. V. (2015). A catalyst platform for unique cationic (co)polymerization in 
aqueous emulsion. Angewandte Chemie International Edition, 54(43), 12728-12732. http://dx.doi.org/10.1002/anie.201501157. PMid:26013180.

13. Radchenko, A. V., Kostjuk, S. V., Vasilenko, I. V., Ganachaud, F., \& Kaputsky, F. N. (2007). Controlled/living cationic polymerization of styrene with BF3OEt2 as a coinitiator in the presence of water: improvements and limitations. European Polymer Journal, 43(6), 2576-2583. http://dx.doi.org/10.1016/j. eurpolymj.2007.03.026.

14. Zhang, X., Guo, W., Wu, Y., Gong, L., Li, W., Li, X., Li, S., Shang, Y., Yang, D., \& Wang, H. (2016). Cationic polymerization of $p$-methylstyrene in selected ionic liquids and polymerization mechanism. Polymer Chemistry, 7(32), 5099-5112. http:// dx.doi.org/10.1039/C6PY00796A.

15. Yoshimitsu, H., Kanazawa, A., Kanaoka, S., \& Aoshima, S. (2016). Cationic polymerization of vinyl ethers with alkyl or ionic side groups in ionic liquids. Journal of Polymer Science. Part A, Polymer Chemistry, 54(12), 1774-1784. http://dx.doi. org/10.1002/pola.28039.

16. Wu, Y., Han, L., Zhang, X., Mao, J., Gong, L., Guo, W., Gu, K., \& Li, S. (2015). Cationic polymerization of isobutyl vinyl ether in an imidazole-based ionic liquid: characteristics and mechanism. Polymer Chemistry, 6(13), 2560-2568. http:// dx.doi.org/10.1039/C4PY01784F.

17. Li, X., Wu, Y., Zhang, J., Li, S., Zhang, M., Yang, D., Wang, H., Shang, Y., Guo, W., \& Yan, P. (2019). Synthesis of highly reactive polyisobutylenes via cationic polymerization in ionic liquids: characteristics and mechanism. Polymer Chemistry, 10(2), 201-208. http://dx.doi.org/10.1039/C8PY01141A.

18. Berezianko, I. A., Vasilenko, I. V., \& Kostjuk, S. V. (2018). Acidic imidazole-based ionic liquids in the presence of diisopropyl ether as catalysts for the synthesis of highly reactive polyisobutylene: effect of ionic liquid nature, catalyst aging, and sonication. Polymer, 145, 382-390. http://dx.doi. org/10.1016/j.polymer.2018.04.059.

19. Berezianko, I. A., Vasilenko, I. V., \& Kostjuk, S. V. (2019). Cationic polymerization of isobutylene co-initiated by chloroferrate imidazole-based ionic liquid: the advantageous effect of initiator and aromatic compounds. European Polymer Journal, 121, 109307. http://dx.doi.org/10.1016/j.eurpolymj.2019.109307.

20. Agner, T., Zimermann, A., Machado, F., Silveira Neto, B. A., Araújo, P. H. H., \& Sayer, C. (2020). Thermal performance of nanoencapsulated phase change material in high molecular weight polystyrene. Polímeros: Ciência e Tecnologia, 30(2), e2020013. http://dx.doi.org/10.1590/0104-1428.01320.

21. Dutra, G. V. S., Teixeira, T. S., Medeiros, G. A., Abdelnur, P. V., Hermes de Araújo, P. H., Sayer, C., Neto, B. A. D., \& Machado, F. (2020). On the role of metal-containing imidazolium-based ionic liquid catalysts in the formation of tailored polystyrene. Industrial \& Engineering Chemistry Research, 59(50), 2168521699. http://dx.doi.org/10.1021/acs.iecr.0c04327.

22. Alves, R. C., Agner, T., Rodrigues, T. S., Machado, F., Neto, B. A. D., Costa, C., Araújo, P. H. H., \& Sayer, C. (2018). Cationic miniemulsion polymerization of styrene mediated by imidazolium based ionic liquid. European Polymer Journal, 104, 51-56. http://dx.doi.org/10.1016/j.eurpolymj.2018.04.035.

23. Ayat, M., Belbachir, M., \& Rahmouni, A. (2017). Synthesis of block copolymers consists on vinylidene chloride and $\alpha$ - methylstyrene by cationic polymerization using an acid exchanged motmorillonite clay as heterogeneous catalyst (Algerian MMT). Journal of Molecular Structure, 1139, 381389. http://dx.doi.org/10.1016/j.molstruc.2017.03.056.

24. Sang, W., \& Yan, Q. (2018). Electro-controlled living cationic polymerization. Angewandte Chemie International Edition, 57(18), 4907-4911. http://dx.doi.org/10.1002/anie.201712270. PMid:29508512.
25. Rodrigues, T. S., Medeiros, G. A., Silva, F. M., \& Neto, B. A. D. (2011). Polimerização do estireno com líquidos iônicos que possuem ácidos de Lewis incorporados na estrutura. In $34^{\circ}$ Reunião Anual da Sociedade Brasileira de Química (p. 1). Florianópolis: Sociedade Brasileira de Química.

26. Bolner, F. M., Jensen, A. T., Sayer, C., Araújo, P. H. H., Machado, F., \& Neto, B. A. D. (2017). Polimerização de estireno com catalisador a base de líquido iônico modificado. In $14^{\circ}$ Congresso Brasileiro de Polímeros (pp. 1-5). Águas de Lindóia: Associação Brasileira de Polímeros.

27. Ramos, J., \& Forcada, J. (2010). The role of cationic monomers in emulsion polymerization. European Polymer Journal, 46(5), 1106-1110. http://dx.doi.org/10.1016/j.eurpolymj.2010.01.012.

28. Dupont, J., Consorti, C. S., Suarez, P. A. Z., Souza, R. F., Fulmer, S. L., Richardson, D. P., Smith, T. E., \& Wolff, S. (2002). Preparation of 1-butyl-3-methyl imidazolium-based room temperature ionic liquids. Organic Syntheses, 79, 236243. http://dx.doi.org/10.15227/orgsyn.079.0236.

29. Ramos, L. M., Guido, B. C., Nobrega, C. C., Corrêa, J. R., Silva, R. G., Oliveira, H. C. B., Gomes, A. F., Gozzo, F. C., \& Neto, B. A. D. (2013). The Biginelli reaction with an imidazolium-tagged recyclable iron catalyst: kinetics, mechanism, and antitumoral activity. Chemistry (Weinheim an der Bergstrasse, Germany), 19(13), 4156-4168. http://dx.doi. org/10.1002/chem.201204314. PMid:23460474.

30. Ahrens, S., Zeller, A., Taige, M., \& Strassner, T. (2006). Extension of the alkane bridge in bisNHC-palladium-chloride complexes. Synthesis, structure, and catalytic activity. Organometallics, 25(22), 5409-5415. http://dx.doi.org/10.1021/om060577a.

31. Rodrigues, T. S., Machado, F., Lalli, P. M., Eberlin, M. N., $\&$ Neto, B. A. D. (2015). Styrene polymerization efficiently catalyzed by iron-containing imidazolium-based ionic liquids: reaction mechanism and enhanced ionic liquid effect. Catalysis Communications, 63, 66-73. http://dx.doi.org/10.1016/j. catcom.2014.11.002.

32. Machado, F., Lima, E. L., \& Pinto, J. C. (2007). Uma revisão sobre os processos de polimerização em suspensão. Polímeros: Ciência e Tecnologia, 17(2), 166-179. http://dx.doi.org/10.1590/ S0104-14282007000200016.

33. Aoshima, S., \& Kanaoka, S. (2009). A renaissance in living cationic polymerization. Chemical Reviews, 109(11), 52455287. http://dx.doi.org/10.1021/cr900225g. PMid:19803510.

34. Islam, M. N., Haldorai, Y., Nguyen, V. H., \& Shim, J.-J. (2014). Synthesis of poly(vinyl pivalate) by atom transfer radical polymerization in supercritical carbon dioxide. European Polymer Journal, 61, 93-104. http://dx.doi.org/10.1016/j. eurpolymj.2014.09.003.

35. Kostjuk, S. V., Dubovik, A. Y., Vasilenkol, I. V., Mardykin, V. P., Gaponik, L. V., Kaputsky, F. N., \& Antipin, L. M. (2004). Novel initiating system based on $\mathrm{AlCl} 3$ etherate for quasiliving cationic polymerization of styrene. Polymer Bulletin, 52(3), 227-234. http://dx.doi.org/10.1007/s00289-004-0280-2.

36. Banerjee, S., Paira, T. K., \& Mandal, T. K. (2013). Control of molecular weight and tacticity in stereospecific living cationic polymerization of $\alpha$-methylstyrene at $0{ }^{\circ} \mathrm{C}$ using $\mathrm{FeCl} 3$-based initiators: effect of tacticity on thermal properties. Macromolecular Chemistry and Physics, 214(12), 1332-1344. http://dx.doi.org/10.1002/macp.201300092.

37. Paira, T. K., Banerjee, S., Raula, M., Kotal,A., Si, S., \& Mandal, T. K. (2010). Peptide-polymer bioconjugates via atom transfer radical polymerization and their solution aggregation into hybrid micro/nanospheres for dye uptake. Macromolecules, 43(9), 4050-4061. http://dx.doi.org/10.1021/ma1001904.

38. Yamada, K., Minoda, M., \& Miyamoto, T. (1999). Controlled synthesis of amphiphilic block copolymers with pendant $N$-acetylD-glucosamine residues by living cationic polymerization and 
their interaction with WGA lectin. Macromolecules, 32(11), 3553-3558. http://dx.doi.org/10.1021/ma9816315.

39. Biedroń, T., \& Kubisa, P. (2004). Cationic polymerization of styrene in a neutral ionic liquid. Journal of Polymer Science. Part A, Polymer Chemistry, 42(13), 3230-3235. http://dx.doi. org/10.1002/pola.20158.

40. Patrocinio, V. M. B., Agner, T., Dutra, G. V. S., Machado, F., Neto, B. A. D., Araújo, P. H. H., \& Sayer, C. (2019). High molecular weight polystyrene obtained by cationic emulsion polymerization catalyzed by imidazolium-based ionic liquid. Macromolecular Reaction Engineering, 13(2), 1800061-1800067. http://dx.doi.org/10.1002/mren.201800061.

41. Banerjee, S., Paira, T. K., Kotal, A., \& Mandal, T. K. (2010). Room temperature living cationic polymerization of styrene with $\mathrm{HX}$-styrenic monomer adduct/ $\mathrm{FeCl} 3$ systems in the presence of tetrabutylammonium halide and tetraalkylphosphonium bromide salts. Polymer, 51(6), 1258-1269. http://dx.doi. org/10.1016/j.polymer.2010.01.051.

42. Medeiros, A. M. M. S., Machado, F., Rubim, J. C., \& McKenna, T. F. L. (2017). Bio-based copolymers obtained through miniemulsion copolymerization of methyl esters of acrylated fatty acids and styrene. Journal of Polymer Science. Part A, Polymer Chemistry, 55(8), 1422-1432. http://dx.doi. org/10.1002/pola.28511.

43. Rieger, J. (1996). The glass transition temperature of polystyrene. Journal of Thermal Analysis, 46(3), 965-972. http://dx.doi. org/10.1007/BF01983614.

44. Szkudlarek, M., Beginn, U., Keul, H., \& Möller, M. (2017). Synthesis of terpolymers with homogeneous composition by free radical copolymerization of maleic anhydride, perfluorooctyl and butyl or dodecyl methacrylates: application of the continuous flow monomer addition technique. Polymers, 9(11), 610. http:// dx.doi.org/10.3390/polym9110610. PMid:30965911.

45. Metanawin, S., Panutumron, P., Thongsale, A., \& Metanawin, T. (2018). The functionalization of hybrid titanium dioxide by miniemulsion polymerization technique. Materials Today: Proceedings, 5(3, Part 2), 9651-9657. http://dx.doi.org/10.1016/j. matpr.2018.01.133.

46. Christie, D., Zhang, C., Fu, J., Koel, B., \& Priestley, R. D. (2016). Glass transition temperature of colloidal polystyrene dispersed in various liquids. Journal of Polymer Science. Part B, Polymer Physics, 54(17), 1776-1783. http://dx.doi org/10.1002/polb.24082.

47. Shen, Y., Du, C., Zhou, J., \& Ma, F. (2018). The facile modification of polyacrylate emulsion via hexadecane to enhance controlled-release profiles of coated urea. Scientific Reports, 8(1), 12279. http://dx.doi.org/10.1038/s41598-01830585-5. PMid:30116004.

48. Gaynor, S. G., Edelman, S., \& Matyjaszewski, K. (1996). Synthesis of branched and hyperbranched polystyrenes. Macromolecules, 29(3), 1079-1081. http://dx.doi.org/10.1021/ ma9513877.

49. Huang, W., Gu, W., Yang, H., Xue, X., Jiang, B., Zhang, D., Fang, J., Chen, J., Yang, Y., \& Guo, J. (2017). Preparation and properties of branched polystyrene through radical suspension polymerization. Polymers, 9(1), 14. http://dx.doi.org/10.3390/ polym9010014. PMid:30970692.

50. Li, B., Liu, W., \& Wu, Y. (2012). Synthesis of long-chain branched isotactic-rich polystyrene via cationic polymerization. Polymer, 53(15), 3194-3202. http://dx.doi.org/10.1016/j. polymer.2012.04.030.

51. Rozentsvet, V. A., Kozlov, V. G., Sablina, N. A., Stotskaya, O. A., Peruch, F., \& Kostjuk, S. V. (2017). New insight into the polymerization mechanism of 1,3-dienes cationic polymerization. IV. Mechanism of unsaturation loss in the polymerization of isoprene. Polymer Chemistry, 8(5), 926-935. http://dx.doi. org/10.1039/C6PY01736C.

52. Artusio, F., Bazzano, M., Pisano, R., Coulon, P. E., Rizza, G., Schiller, T., \& Sangermano, M. (2018). Polymeric nanocapsules via interfacial cationic photopolymerization in miniemulsion. Polymer, 139, 155-162. http://dx.doi. org/10.1016/j.polymer.2018.02.019.

Received: May 05, 2020

Revised: Feb. 14, 2021

Accepted: Feb. 18, 2021 


\section{Supplementary Material}

Supplementary material accompanies this paper.

Figure S1. 1H-NMR spectrum of BMI.Cl (CDCl3, $600 \mathrm{MHz})$.

Figure S2. 1H-NMR spectrum of MAI·Cl (D2O, $600 \mathrm{MHz}$ )

Figure S3. 13C-NMR spectrum of MAI·Cl (D2O, $600 \mathrm{MHz})$.

Figure S4. 1H-NMR spectrum of bMIE.2Cl (D2O, $600 \mathrm{MHz})$.

Figure S5. 13C-NMR spectrum of bMIE.2Cl (D2O, $600 \mathrm{MHz})$.

Figure S6. Photograph of the synthesized polymers using the catalysts BMI-Fe2Cl7, MAI·Fe2Cl7 and bMIE-2Fe2Cl7 (a) before and (b) after purification.

Figure S7. 1H-NMR spectrum of unpurified polystyrene sample synthesized using BMI-Fe2 $\mathrm{Cl} 7$ catalyst at $85^{\circ} \mathrm{C}(\mathrm{CDCl}$, $600 \mathrm{MHz})$.

Table S1. Conversion, average diameter of the monomer droplets (initial Dp) and polymeric particles (final $\mathrm{Dp}$ ) and polydispersity index for all polymerizations after $8 \mathrm{~h}$ of reaction.

Figure S8. 1H-NMR spectrum of the vinyl pivalate polymerization test in the presence of $\mathrm{BMI} \cdot \mathrm{Fe} 2 \mathrm{Cl} 7(\mathrm{CDCl} 3,600 \mathrm{MHz})$ Table S2. Average molar masses and molar-mass dispersity as a function of conversion (Xp) of the polymers synthesized at $85^{\circ} \mathrm{C}$ using ILs catalysts.

Figure S9. 1H-NMR spectra of purified polystyrene samples synthesized using (a) BMI-Fe2Cl7; (b) MAI-Fe2Cl7 and (c) bMIE-2Fe2 $\mathrm{Cl} 7$ at $85^{\circ} \mathrm{C}(\mathrm{CDCl} 3,600 \mathrm{MHz})$.

Figure S10. 13C-NMR spectra of purified polystyrene samples synthesized using (a) BMI-Fe2Cl7; (b) MAI.Fe2 $\mathrm{Cl} 7$ and (c) bMIE.2Fe2 $\mathrm{Cl} 7$ at $85^{\circ} \mathrm{C}(\mathrm{CDCl} 3,600 \mathrm{MHz})$.

This material is available as part of the online article from http://www.scielo.br/po 